\title{
Late-glacial to late-Holocene shifts in global precipitation $\delta^{18} \mathrm{O}$
}

\author{
S. Jasechko ${ }^{1,2}$, A. Lechler ${ }^{3}$, F. S. R. Pausata ${ }^{4}$, P. J. Fawcett ${ }^{1}$, T. Gleeson ${ }^{5}$, D. I. Cendón ${ }^{6}$, J. Galewsky ${ }^{1}$, \\ A. N. LeGrande ${ }^{7}$, C. Risi ${ }^{8}$, Z. D. Sharp ${ }^{1}$, J. M. Welker ${ }^{9}$, M. Werner ${ }^{10}$, and K. Yoshimura ${ }^{11}$ \\ ${ }^{1}$ Department of Earth and Planetary Sciences, University of New Mexico, Albuquerque, New Mexico, USA \\ ${ }^{2}$ Department of Geography, University of Calgary, Calgary, Alberta, Canada \\ ${ }^{3}$ Department of Geosciences, Pacific Lutheran University, Tacoma, USA \\ ${ }^{4}$ Department of Meteorology and Bolin Center for Climate Research, Stockholm University, Stockholm, Sweden \\ ${ }^{5}$ Department of Civil Engineering, University of Victoria, Victoria, Canada \\ ${ }^{6}$ Australian Nuclear Science and Technology Organisation, Sydney, Australia \\ ${ }^{7}$ NASA Goddard Institute for Space Studies, New York, USA \\ ${ }^{8}$ Laboratoire de Météorologie Dynamique, IPSL, UPMC, CNRS, Paris, France \\ ${ }^{9}$ Department of Biological Sciences, University of Alaska Anchorage, Anchorage, Alaska, USA \\ ${ }^{10}$ Alfred Wegener Institute, Helmholtz Centre for Polar and Marine Research, Bremerhaven, Germany \\ ${ }^{11}$ Atmosphere and Ocean Research Institute, University of Tokyo, Kashiwa, Japan
}

Correspondence to: S. Jasechko (sjasechk@ucalgary.ca)

Received: 28 February 2015 - Published in Clim. Past Discuss.: 27 March 2015

Revised: 22 September 2015 - Accepted: 5 October 2015 - Published: 14 October 2015

\begin{abstract}
Reconstructions of Quaternary climate are often based on the isotopic content of paleo-precipitation preserved in proxy records. While many paleo-precipitation isotope records are available, few studies have synthesized these dispersed records to explore spatial patterns of late-glacial precipitation $\delta^{18} \mathrm{O}$. Here we present a synthesis of 86 globally distributed groundwater $(n=59)$, cave calcite $(n=15)$ and ice core $(n=12)$ isotope records spanning the late-glacial (defined as $\sim 50000$ to $\sim 20000$ years ago) to the late-Holocene (within the past $\sim 5000$ years). We show that precipitation $\delta^{18} \mathrm{O}$ changes from the late-glacial to the late-Holocene range from $-7.1 \%$ o $\left(\delta^{18} \mathrm{O}_{\text {late-Holocene }}>\delta^{18} \mathrm{O}_{\text {late-glacial }}\right)$ to $+1.7 \%$ o $\left(\delta^{18} \mathrm{O}_{\text {late-glacial }}>\delta^{18} \mathrm{O}_{\text {late-Holocene }}\right)$, with the majority $(77 \%)$ of records having lower late-glacial $\delta^{18} \mathrm{O}$ than late-Holocene $\delta^{18} \mathrm{O}$ values. High-magnitude, negative precipitation $\delta^{18} \mathrm{O}$ shifts are common at high latitudes, high altitudes and continental interiors $\left(\delta^{18} \mathrm{O}_{\text {late-Holocene }}>\delta^{18} \mathrm{O}_{\text {late-glacial }}\right.$ by more than $3 \%$ ). Conversely, low-magnitude, positive precipitation $\delta^{18} \mathrm{O}$ shifts are concentrated along tropical and subtropical coasts $\left(\delta^{18} \mathrm{O}_{\text {late-glacial }}>\delta^{18} \mathrm{O}_{\text {late-Holocene }}\right.$ by less than $2 \%$ ). Broad, global patterns of late-glacial to late-Holocene precipitation $\delta^{18} \mathrm{O}$ shifts suggest that stronger-than-modern isotopic distillation of air masses prevailed during the late-
\end{abstract}

glacial, likely impacted by larger global temperature differences between the tropics and the poles. Further, to test how well general circulation models reproduce global precipitation $\delta^{18} \mathrm{O}$ shifts, we compiled simulated precipitation $\delta^{18} \mathrm{O}$ shifts from five isotope-enabled general circulation models simulated under recent and last glacial maximum climate states. Climate simulations generally show better intermodel and model-measurement agreement in temperate regions than in the tropics, highlighting a need for further research to better understand how inter-model spread in convective rainout, seawater $\delta^{18} \mathrm{O}$ and glacial topography parameterizations impact simulated precipitation $\delta^{18} \mathrm{O}$. Future research on paleo-precipitation $\delta^{18} \mathrm{O}$ records can use the global maps of measured and simulated late-glacial precipitation isotope compositions to target and prioritize field sites.

\section{Introduction}

Isotopic compositions of late-glacial precipitation can be preserved in groundwaters, cave calcite, glacial ice, ground ice and lake sediments. These records have been used to better understand past climate changes for more than a half century (e.g., Münnich, 1957; Thatcher et al., 1961; Münnich et 
al., 1967; Pearson and White, 1967; Tamers, 1967; Gat et al., 1969). Each type of isotopic proxy record is distinguished by its temporal resolution, preservation of one or both ${ }^{18} \mathrm{O} /{ }^{16} \mathrm{O}$ and ${ }^{2} \mathrm{H} /{ }^{1} \mathrm{H}$ ratios, and frequency on land surface. For example, groundwater records contain both ${ }^{18} \mathrm{O} /{ }^{16} \mathrm{O}$ and ${ }^{2} \mathrm{H} /{ }^{1} \mathrm{H}$ ratios with widespread global occurrence, but have a coarser temporal resolution than other paleoclimate proxies (Rozanski, 1985; Edmunds and Milne, 2001; Edmunds, 2009; Corcho Alvarado et al., 2011; Jiráková et al., 2011). Speleothem records, by contrast, have high temporal resolution but usually only report calcite ${ }^{18} \mathrm{O} /{ }^{16} \mathrm{O}$ ratios (without fluid inclusion ${ }^{2} \mathrm{H} /{ }^{1} \mathrm{H}$ data) and are less common than groundwater records (e.g., Harmon et al., 1978, 1979). Late-glacial ice core and ground ice records have high temporal resolution, can be analysed for ${ }^{18} \mathrm{O} /{ }^{16} \mathrm{O}$ and ${ }^{2} \mathrm{H} /{ }^{1} \mathrm{H}$ ratios, but are rare on non-polar lands (Dansgaard et al., 1982; Thompson et al., 1989, 1995, 1997, 1998). Lake sediment records can have a high temporal resolution, can preserve ${ }^{18} \mathrm{O} /{ }^{16} \mathrm{O}$ and ${ }^{2} \mathrm{H} /{ }^{1} \mathrm{H}$ ratios and are available for a multitude of globally distributed locations (e.g., Edwards and McAndrews, 1989; Eawag et al., 1992; Menking et al., 1997; Wolfe et al., 2000; Anderson et al., 2001; Beuning et al., 2002; Sachse et al., 2004; Morley et al., 2005; Tierney et al., 2008). However, some lake water proxy isotope records may be impacted by paleo-lake evaporative isotope effects that obscure the primary meteoric water signal and mask paleo-precipitation isotope compositions (e.g., lake sediment calcite, diatom silica; Leng and Marshall, 2004).

This study examines speleothem, ice core and groundwater isotope records, focusing primarily on the groundwater isotope records due to their relative density in the published literature in comparison to the more limited number of published speleothem and ice core records (compilations by Pedro et al., 2011; Stenni et al., 2011; Clark et al., 2012; Shah et al., 2013; Caley et al., 2014a). There exist roughly twice as many groundwater reconstructions of late-glacial to late-Holocene precipitation $\delta^{18} \mathrm{O}$ shifts $(n=59)$ as the combined total of speleothem and ice core records ( $n=27$; where $\delta^{18} \mathrm{O}=\left({ }^{18} \mathrm{O} /{ }^{16} \mathrm{O}_{\text {sample }}\right) /\left({ }^{18} \mathrm{O} /{ }^{16} \mathrm{O}_{\text {standard mean ocean water }}{ }^{-}\right.$ 1) $\times 1000$ ). A recent global synthesis of paired precipitationgroundwater isotopic data demonstrated that modern annual precipitation and modern groundwater isotope compositions follow systematic relationships with some bias toward winter and wet-season precipitation (Jasechko et al., 2014). Systematic rainfall-recharge relationships shown by Jasechko et al. (2014) support our primary assumption in this study that groundwater isotope compositions closely reflect meteoric water. Because groundwater records can only identify climate change occurring over thousands of years due to hydrodynamic dispersion during multi-millennial residence times (e.g., Davison and Airey, 1982; Stute and Deak, 1989), we limit the focus of this study to meteoric water isotope composition changes from the latter half of the last glacial time period to the late-Holocene. The latter half of the last glacial period is defined as $\sim 20000$ to $\sim 50000$ years before present, using the end of the last glacial maximum as the more recent age limit ( 20000 years before present; Clark et al., 2009) and the maximum age of groundwater that can be identified by ${ }^{14} \mathrm{C}$ dating as an approximate upper age limit (i.e., groundwater ages more recent than $\sim 50000$ years old).

For brevity, we refer herein to the time period representing the latter half of the last glacial period $(\sim 20000$ to $\sim 50000$ years before present) as the late-glacial (e.g., $\delta^{18} \mathrm{O}_{\text {late-glacial }}$. We adopt a definition of the late-Holocene as occurring within the last 5000 years following Thompson et al. (2006). Other work proposes the late-Holocene be defined as within the last 4200 years (Walker et al., 2012), which is consistent with the 5000 years before present definition (Thompson et al., 2006) within the practical uncertainty of ${ }^{14} \mathrm{C}$-based groundwater ages $\left( \pm \sim 10^{3}\right.$ years). Further, although precipitation isotope compositions have varied over the late-Holocene, groundwater mixing integrates this variability, prohibiting paleoclimate interpretation at finer temporal resolutions.

Late-glacial to late-Holocene changes in precipitation isotope compositions provide important insights into conditions and processes of the past. Perhaps the two best-constrained global-in-scale differences between the late-glacial and the late-Holocene are changes to oceanic and atmospheric temperatures (MARGO Members, 2009; Shakun and Carlson, 2010; Annan and Hargreaves, 2013), and changes to seawater $\delta^{18} \mathrm{O}$ (Emiliani, 1955; Dansgaard and Tauber, 1969; Schrag et al., 1996, 2002). Atmospheric temperatures have increased by a global average of $\sim 4^{\circ} \mathrm{C}$ since the last glacial maximum, with greatest warming at the poles and more modest warming at lower latitudes (Fig. 1; Shakun and Carlson, 2010; Annan and Hargreaves, 2013). Seawater $\delta^{18} \mathrm{O}$ during the last glacial maximum was $1.0 \pm 0.1 \%$ o higher than the modern ocean, as constrained by paleo-ocean water samples collected from pore waters trapped within sea floor sediments (Schrag et al., 2002).

Previous studies have proposed many different interpretations of past changes to precipitation isotope compositions. Records of paleo-precipitation $\delta^{18} \mathrm{O}$ have been used as a proxy for regional land surface and atmospheric temperature (e.g., Rozanski, 1985; Nikolayev and Mikhalev, 1995; Johnsen et al., 2001; Grasby and Chen, 2005; Akouvi et al., 2008; Bakari et al., 2012); however, $\delta^{18}$ O-based paleotemperatures can be complicated by past changes to a variety of other processes controlling precipitation $\delta^{18} \mathrm{O}$, including moisture sources, upwind rainout, transport pathways, moisture recycling and in-cloud processes (Ciais and Jouzel, 1994; Masson-Delmotte et al., 2005; Sjostrom and Welker, 2009). Process-based explanations for observed meteoric water $\delta^{18} \mathrm{O}$ variations in proxy records include changes to hurricane intensity (e.g., Plummer, 1993), large-scale atmospheric circulation (e.g., Rozanski, 1985; Weyhenmeyer et al., 2000; McDermott et al., 2001; Pausata et al., 2009; Asmerom et al., 2010; Oster et al., 2015), aridity (e.g., Wagner et al., 2010), monsoon strength (e.g., Denniston et al., 2000; Lachniet et 

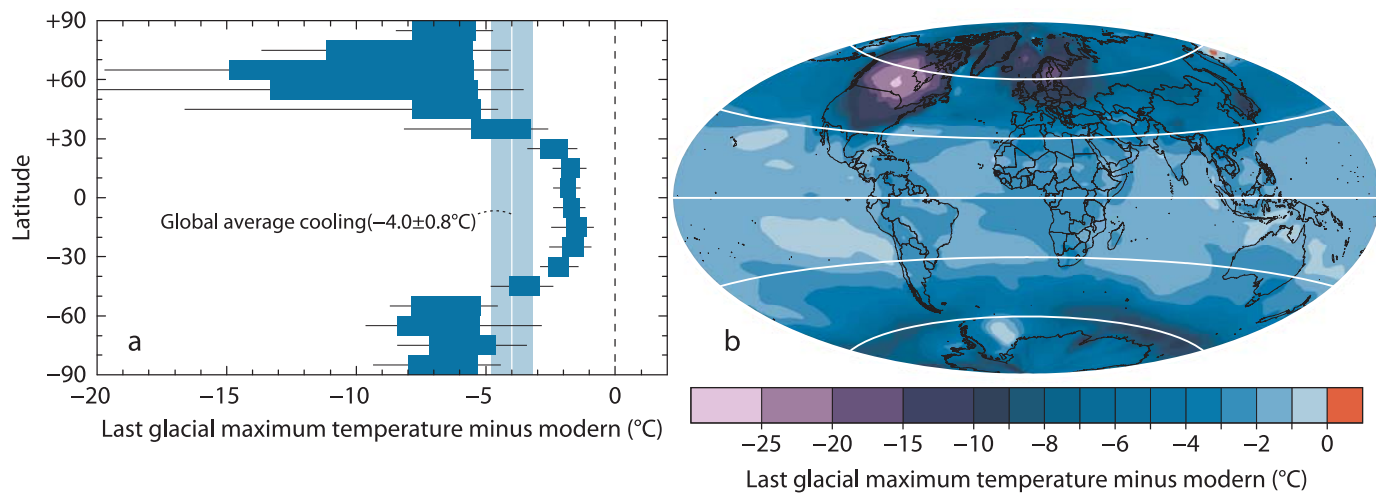

Figure 1. The change in surface air temperatures from the last glacial maximum to the preindustrial era (gridded data from Annan and Hargreaves, 2013). (a) Percentile ranges of temperature changes since the last glacial maximum for 10 degree latitudinal bands. Blue shading marks the 25th-75th percentile range; thin horizontal lines mark the 10th-90th percentile range. The grey band shows the globally averaged estimate of temperature change since the last glacial maximum of $-4.0 \pm 0.8^{\circ} \mathrm{C}$. (b) Gridded surface air temperature anomaly from the last glacial maximum to the preindustrial era (data from Annan and Hargreaves, 2013).

al., 2004; Liu et al., 2007; Pausata et al., 2011a), local seawater $\delta^{18} \mathrm{O}$ (Wood et al., 2003; Feng et al., 2014), precipitation seasonality (e.g., Fawcett et al., 1997; Werner et al., 2000; Cruz et al., 2005), moisture provenance (e.g., Sjostrom and Welker, 2009; Lewis et al., 2010), storm tracks, climate oscillation modes (e.g., North Atlantic oscillation), moisture recycling (e.g., Winnick et al., 2013, 2014; Liu et al., 2014a, b) and groundwater flow path architecture (Purdy et al., 1996; Stewart et al., 2004; Morrissey et al., 2010; Hagedorn, 2015). While unravelling these mechanisms and delineating the primary and secondary processes can be rather challenging, the use of climate models in combination with robust and extensive precipitation isotope data can resolve many of these complexities with meaningful interpretations and insight.

The objective of this study is to analyse spatial patterns of measured late-glacial to late-Holocene precipitation $\delta^{18} \mathrm{O}$ changes from published groundwater, ground ice, glacial ice and cave calcite records, and to compare these measurements with output from five state-of-the-art isotope-enabled general circulation model simulations of last glacial maximum and pre-industrial or modern climate conditions. Synthesizing paleowater $\delta^{18} \mathrm{O}$ records provides an important constraint for isotope-enabled general circulation model simulations of atmospheric and hydrologic conditions during glacial climate states (Jouzel et al., 2000). We combine a new global compilation of late-glacial groundwater and ground ice isotope data ( $n=59)$ with existing compilations for speleothems $(n=15$; Shah et al., 2013) and ice cores ( $n=12$; Pedro et al., 2011; Stenni et al., 2011; Clark et al., 2012; Caley et al., 2014a). This compilation of late-glacial groundwater isotope compositions builds from earlier reviews of European and African paleowater isotope compositions (Rozanski, 1985; Edmunds and Milne, 2001; Darling, 2004; Edmunds, 2009; Négrel and Petelet-Giraud, 2011; Jiráková et al., 2011).

\section{Data set and methods}

In order to examine spatial patterns of change to meteoric water $\delta^{18} \mathrm{O}$ values we compiled $\delta^{18} \mathrm{O}, \delta^{2} \mathrm{H}, \delta^{13} \mathrm{C}$ and ${ }^{14} \mathrm{C}$ data from 1713 groundwater samples collected from 59 aquifer systems reported in 76 publications (data and primary references presented in the Supplement). $\delta^{13} \mathrm{C},{ }^{3} \mathrm{H}$ and ${ }^{14} \mathrm{C}$ data were used to estimate groundwater age (details within Supplement). Changes to precipitation $\delta^{18} \mathrm{O}$ values over time were determined by comparing groundwater isotope compositions of the late-Holocene $\left(\delta^{18} \mathrm{O}_{\text {late-Holocene }}\right.$ defined here as less than 5000 years before present; Thompson et al., 2006) and the latter half of the last glacial time period ( $\delta^{18} \mathrm{O}_{\text {late-glacial }}: 20000$ to $\sim 50000$ years before present). We acknowledge that these two relatively long time intervals necessarily long in order to examine groundwater isotope records - integrate precipitation $\delta^{18} \mathrm{O}$ variability over the course of each time interval. The late-Holocene time interval integrates known precipitation $\delta^{18} \mathrm{O}$ variability (e.g., Aichner et al., 2015), and the late-glacial time interval likely incorporates groundwater preceding the last glacial maximum, potentially during Marine Isotope Stage 3 or even older glacial time periods due to large uncertainties in ${ }^{14} \mathrm{C}$-based groundwater ages (Supplement).

Proxy-based meteoric water $\delta^{18} \mathrm{O}$ changes from the latter half of the last glacial time period to the late-Holocene are described herein as measured $\Delta^{18} O_{\text {late-glacial, where }}$ measured $\Delta^{18} \mathrm{O}_{\text {late-glacial }}=\delta^{18} \mathrm{O}_{\text {late-glacial }}-\delta^{18} \mathrm{O}_{\text {late-Holocene }}$. A minimum groundwater age of 20000 years before present was used to define the late-glacial to remain consistent with the timing of the last glacial maximum $(\sim 20000$ years before present; Clark et al., 2009). Samples having a deuterium excess of less than zero (deuterium excess $=\delta^{2} \mathrm{H}$ $-8 \times \delta^{18} \mathrm{O}$; Dansgaard, 1964) and falling along regionally characteristic evaporation $\delta^{2} \mathrm{H} / \delta^{18} \mathrm{O}$ slopes (Gibson et 
al., 2008) were removed from the analysis to avoid including groundwater samples impacted by partial evaporation. Further, studies reporting saltwater intrusion were avoided on the basis of groundwater $\delta^{18} \mathrm{O}$ and salinities showing evidence of seawater mixing (e.g., Schiavo et al., 2009; Yechieli et al., 2009; Hamouda et al., 2011; Han et al., 2011; Wang and Jiao, 2012; Currell et al., 2013). The 59 compiled groundwater measured $\Delta^{18} \mathrm{O}_{\text {late-glacial }}$ values are unevenly distributed among western Europe $(n=10)$, eastern Europe and the Middle-East $(n=12)$, Africa $(n=17)$, southeastern Asia $(n=6)$, Australia, Oceania and the Malay Archipelago $(n=2)$, South America $(n=2)$, temperate and subtropical North America $(n=8)$ and the High Arctic $(n=2)$. Half of the compiled groundwater records are located in the tropics or subtropics (that is, within $35^{\circ}$ of the equator; $n=29$ ) and half are located in the extra-tropics $(n=30)$.

Speleothem and ice core isotope proxy records were also compiled. Lacustrine sediment $\delta^{18} \mathrm{O}$ records are not considered in this study because these records may preserve meteoric waters impacted by evaporative isotope effects (Leng and Marshall, 2004). Speleothem and ice core measured $\Delta^{18} \mathrm{O}_{\text {late-glacial }}$ values were calculated by subtracting average $\delta^{18} \mathrm{O}$ values for each of the two time intervals defined for the groundwater records: the late-Holocene $(<5000$ years before present) and latter half of the last glacial time period (20000 to 50000 years before present). This step effectively lowered the temporal resolution of speleothem and ice core precipitation isotope records to be consistent with the temporal resolution of the groundwater records. A correction factor was applied to speleothem $\delta^{18} \mathrm{O}$ values to account for different $\mathrm{H}_{2} \mathrm{O}-\mathrm{CaCO}_{3}$ isotopic fractionation factors during the lateglacial and the late-Holocene because of differing land surface temperatures during each time period (details presented within Supplement).

Simulated $\Delta^{18} \mathrm{O}_{\text {late-glacial }}$ values were compiled from five isotope-enabled general circulation models (simulated $\Delta^{18} \mathrm{O}_{\text {late-glacial }}=\delta^{18} \mathrm{O}_{\text {last glacial maximum }}-\delta^{18} \mathrm{O}_{\text {pre-industrial }}$ ): CAM3iso (e.g., Noone and Sturm, 2010; Pausata et al., 2011a), ECHAM5-wiso (e.g., Werner et al., 2011), GISSE2R (e.g., Schmidt et al., 2014; LeGrande and Schmidt, 2008, 2009), IsoGSM (e.g., Yoshimura et al., 2003) and LMDZ4 (e.g., Risi et al., 2010a). ECHAM5-wiso and IsoGSM outputs are for modern climate rather than pre-industrial conditions; however, the difference between the isotopic composition of pre-industrial and modern climate are expectedly small compared to late-glacial to late-Holocene $\delta^{18} \mathrm{O}$ shifts. An offset factor was applied to simulated mean seawater $\delta^{18} \mathrm{O}$ in all five models (Table $\mathrm{S} 1$ in the Supplement) to account for known glacial-interglacial changes to seawater $\delta^{18} \mathrm{O}$ (Emiliani, 1955; Dansgaard and Tauber, 1969; Schrag et al., 1996, 2002). Possible spatial differences in seawater $\delta^{18} \mathrm{O}$ changes from the last glacial maximum to the pre-industrial time period are not incorporated into simulations with prescribed sea surface temperatures (CAM3iso, ECHAM5-wiso, IsoGSM, LMDZ4) but are simulated by the coupled ocean-atmosphere simulation of GISSE2-R (Table S1). GISSE2-R was submitted to the CMIP5 archive and participated in PMIP3. LMDZ4 was submitted to the CMIP3 archive. ECHAM5 and CAM3iso did not participate in CMIP5, while IsoGSM uses different boundary conditions than proposed for CMIP5 (Yoshimura et al., 2008). The five models span a range of spatio-temporal resolutions and isotopic/atmospheric parameterizations described in detail in the above references. A selection of the inter-model similarities and differences are summarized in Table S1.

For clarity, empirical $\Delta^{18} \mathrm{O}_{\text {late-glacial values that are }}$ based on measured isotope contents of groundwater, speleothem, ground ice or ice core records are referred to herein as measured $\Delta^{18} \mathrm{O}_{\text {late-glacial }}$; simulated precipitation isotope compositions obtained from general circulation model results are referred to as simulated $\Delta^{18} \mathrm{O}_{\text {late-glacial }}$. We acknowledge that the general circulation models explicitly analyse the last glacial maximum and the pre-industrial climate conditions (i.e., simulated $\left.\Delta^{18} \mathrm{O}_{\text {late-glacial }}=\delta^{18} \mathrm{O}_{\text {last glacial maximum }}-\delta^{18} \mathrm{O}_{\text {pre-industrial }}\right)$, whereas proxy record reconstructions of $\Delta^{18} \mathrm{O}_{\text {late-glacial }}$ integrate hydroclimatology over multi-millennial timescales that are different from the model simulations.

\section{Results and discussion}

\subsection{Measured $\Delta^{18} \mathrm{O}_{\text {late-glacial values }}$}

Measured groundwater $(n=59)$, speleothem $(n=15)$ and ice core $(n=12) \quad \Delta^{18} \mathrm{O}_{\text {late-glacial }}$ values are presented in Fig. 2 (references presented in the Supplement). Measured $\Delta^{18} \mathrm{O}_{\text {late-glacial values range from }-7.1 \% \text { o }}$ (i.e., $\quad \delta^{18} \mathrm{O}_{\text {late-glacial }}<\delta^{18} \mathrm{O}_{\text {late-Holocene) }}$ to $+1.7 \%$ (i.e., $\delta^{18} \mathrm{O}_{\text {late-glacial }}>\delta^{18} \mathrm{O}_{\text {late-Holocene). Three-quarters of the }}$ compiled records have negative measured $\Delta^{18} \mathrm{O}_{\text {late-glacial }}$ values and one-quarter of compiled records have positive measured $\Delta^{18} \mathrm{O}_{\text {late-glacial }}$ values. Most groundwater-based late-glacial to late-Holocene shifts fall along $\delta^{2} \mathrm{H} / \delta^{18} \mathrm{O}$ slopes of $\sim 8$ (Fig. S58 in the Supplement), suggesting that most groundwaters record temporal shifts to precipitation isotope contents rather than to soil evaporation isotope effects (see Evaristo et al., 2015). More than $80 \%$ of records with positive measured $\Delta^{18} \mathrm{O}_{\text {late-glacial }}$ values are located within $35^{\circ}$ of the equator and within $400 \mathrm{~km}$ of the nearest coastline (e.g., Bangladesh $\Delta^{18} \mathrm{O}_{\text {late-glacial }}$ of $+1.5 \%$, less than $300 \mathrm{~km}$ from the coast; Figs. 2-4). In comparison, negative measured $\Delta^{18} \mathrm{O}_{\text {late-glacial values are found in both }}$ coastal regions and farther inland. Negative measured $\Delta^{18} \mathrm{O}_{\text {late-glacial }}$ values of the greatest magnitude are located at high latitudes (e.g., northwestern Canada, latitude $64^{\circ} \mathrm{N}$ : $\Delta^{18} \mathrm{O}_{\text {late-glacial }}$ of $-5.5 \%$; northern Russia latitude $72^{\circ} \mathrm{N}$ : $-5.4 \%$ o) and far from coastlines (e.g., Hungary: $-3.7 \%$, $\sim 500 \mathrm{~km}$ from Atlantic Ocean; Peru: $-6.3 \%$, $\sim 2000 \mathrm{~km}$ from Atlantic Ocean, the modern moisture source to Peru; Garreaud et al., 2009). Greenland and Antarctic ice cores 


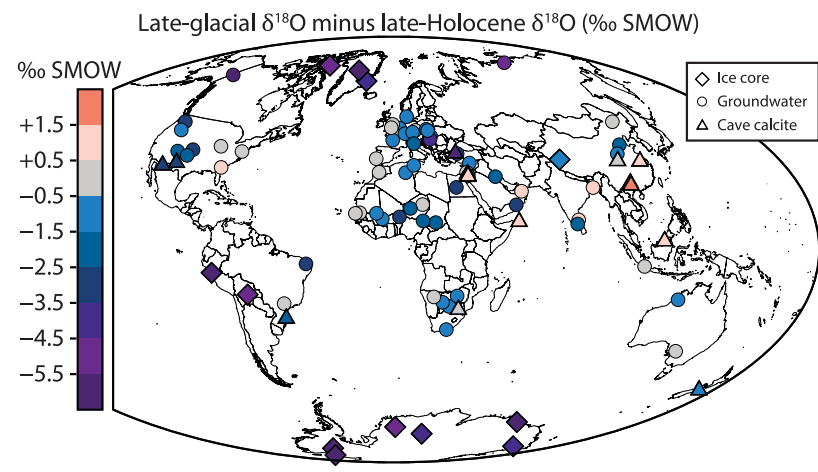

Figure 2. Meteoric water $\delta^{18} \mathrm{O}$ change from the late-glacial (20000 to $\sim 50000$ years ago) to the late-Holocene (within past $\sim 5000$ years; average $\Delta^{18} \mathrm{O}_{\text {late-glacial values shown, }}$ where $\left.\Delta^{18} \mathrm{O}_{\text {late-glacial }}=\delta^{18} \mathrm{O}_{\text {late-glacial }}-\delta^{18} \mathrm{O}_{\text {late-Holocene }}\right)$. The low temporal resolution of groundwater records means that $\delta^{18} \mathrm{O}$ variations within each time period are smoothed and likely represent unequal temporal weighting. References for measured meteoric water $\delta^{18} \mathrm{O}$ changes for ice cores, groundwater and cave calcite are presented in the Supplement.

have negative measured $\Delta^{18} \mathrm{O}_{\text {late-glacial }}$ values that are of greater magnitude than non-polar measured $\Delta^{18} \mathrm{O}_{\text {late-glacial }}$ values (Antarctic and Greenland $\Delta^{18} \mathrm{O}_{\text {late-glacial }}$ values range from -3.6 to $-7.1 \%$; Fig. 3).

Our synthesis shows that measured $\Delta{ }^{18} \mathrm{O}_{\text {late-glacial val- }}$ ues in the tropics are closer to $0 \%$ (i.e., no change) than $\Delta^{18} \mathrm{O}_{\text {late-glacial }}$ values at high latitudes and continental interiors that generally have high magnitude, negative $\Delta^{18} \mathrm{O}_{\text {late-glacial }}$ values. High magnitude, negative measured $\Delta^{18} \mathrm{O}_{\text {late-glacial }}$ values are most common where present-day precipitation $\delta^{18} \mathrm{O}$ values are at a minimum (e.g., Bowen and Wilkinson, 2002). This broad spatial pattern is consistent with the non-linear isotopic distillation of air masses undergoing progressive rainout (i.e., Rayleigh distillation). Because seawater $\delta^{18} \mathrm{O}$ values were $\sim 1 \%$ higher-than-modern during the last glacial maximum (Schrag et al., 1996, 2002), our finding that the majority of measured $\Delta^{18} \mathrm{O}_{\text {late-glacial }}$ values are negative suggests that isotopic distillation of air masses was greater during the late-glacial than under present climate. This finding is consistent with land surface temperature reconstructions that show larger glacial-to-modern changes to land temperatures at high latitude and continental settings (Fig. 1; Annan and Hargreaves, 2013). Tropical versus extratropical patterns of late-glacial/late-Holocene temperature change (Fig. 1a) are broadly similar to measured $\Delta^{18} \mathrm{O}_{\text {late-glacial }}$ values (Fig. 3), where both temperature and isotope shifts are greater at high latitudes relative to the equator. Therefore, it is possible that the larger late-glacial to lateHolocene temperature shifts at the poles relative to the equator may have served to amplify the non-linear, Rayleigh relationship describing the heavy isotope depletion of air masses undergoing progressive rainout during transport from lower

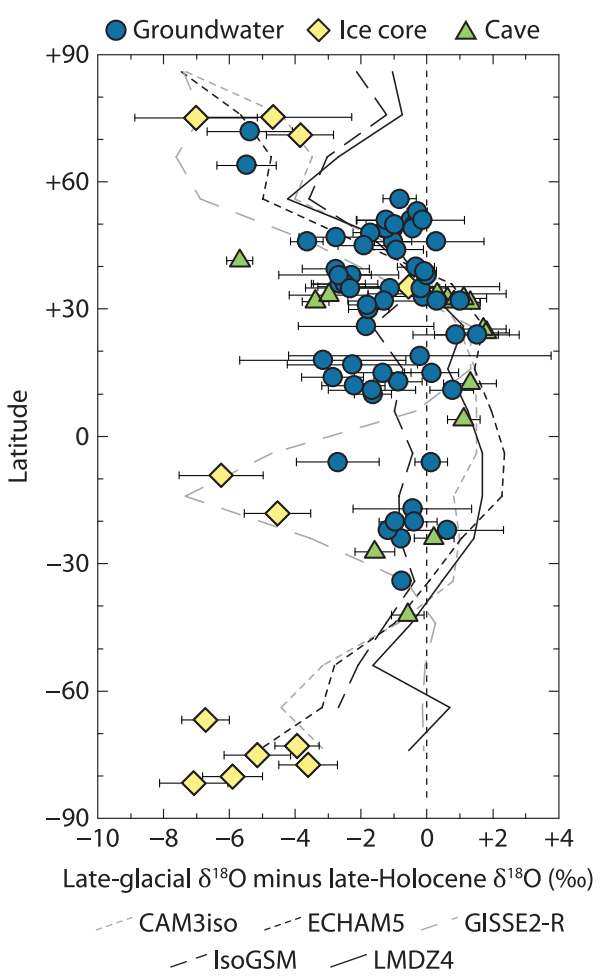

Figure 3. Latitudinal variations of $\Delta^{18} \mathrm{O}_{\text {late-glacial values of }}$ groundwater (circles, each circle is one aquifer), ice cores (diamonds) and cave calcite (i.e., triangles; where $\Delta^{18} \mathrm{O}_{\text {late-glacial }}=$ $\left.\delta^{18} \mathrm{O}_{\text {late-glacial }}-\delta^{18} \mathrm{O}_{\text {late-Holocene }}\right)$. Dashed lines mark $10^{\circ}$ zonal

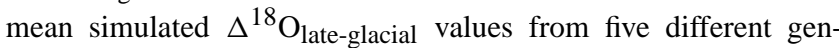
eral circulation models: CAM3iso, ECHAM5-wiso, GISSE2-R, IsoGSM and LMDZ4 (Yoshimura et al., 2003; Legrande and Schmidt, 2008, 2009; Risi et al., 2010a; Noone and Sturm, 2010; Pausata et al., 2011a; Werner et al., 2011).

to higher latitudes. Further, the late-glacial was characterized by (i) lower-than-modern atmospheric temperatures with larger coastal-inland gradients, and (ii) lower-than-modern eustatic sea level leading to longer overland atmospheric transport distances. Each of these late-glacial/late-Holocene changes favours stronger-than-modern isotopic distillation of air masses transported inland from the coast during the late-glacial (Dansgaard, 1964; Rozanski, 1993; Winnick et al., 2014), potentially contributing to the broad, global observation that most $(77 \%) \delta^{18} \mathrm{O}_{\text {late-Holocene }}$ values exceed $\delta^{18} \mathrm{O}_{\text {late-glacial }}$ values on continents.

Pairings of groundwater and speleothem records are available within $\sim 500 \mathrm{~km}$ of one another in the southwestern USA, central China and Israel. Southwestern USA speleothem and groundwater records $\sim 400 \mathrm{~km}$ apart show similar $\Delta^{18} \mathrm{O}_{\text {late-glacial }}$ values, with San Juan Basin groundwaters having a measured $\Delta^{18} \mathrm{O}_{\text {late-glacial }}$ value of $-2.5 \pm 1.0 \%$ (Phillips et al., 1986) and speleothems $\sim 400 \mathrm{~km}$ to the south having measured $\Delta^{18} \mathrm{O}_{\text {late-glacial }}$ values of $-3.0 \pm 1.2$ and $-3.4 \pm 0.4$ (Asmerom et al., 
2010; Wagner et al., 2010). Central China speleothem and groundwater records $\sim 200 \mathrm{~km}$ apart overlap within uncertainty margins (i.e., $\Delta^{18} \mathrm{O}_{\text {late-glacial }}$ values of $-1.1 \pm 1.7$ and $+0.3 \pm 2.1 \%$; Cai et al., 2010). Israeli speleothem and groundwater records $\sim 100 \mathrm{~km}$ apart have different measured $\Delta^{18} \mathrm{O}_{\text {late-glacial }}$ values. Two Israeli groundwater $\Delta{ }^{18} \mathrm{O}_{\text {late-glacial }}$ records were compiled; the coastal Israeli aquifer has a $\Delta^{18} \mathrm{O}_{\text {late-glacial }}$ value of $+0.3 \pm 0.4 \%$ (Yechieli et al., 2009), whereas groundwater of the Dead Sea Rift Val-

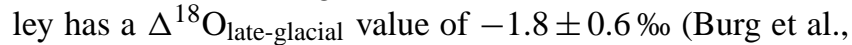
2013). Speleothem records have $\Delta^{18} \mathrm{O}_{\text {late-glacial values close }}$ to $+1 \%$ o (Frumkin et al., 1999; Bar-Matthews et al., 2003). In northern Turkey, speleothem and groundwater separated

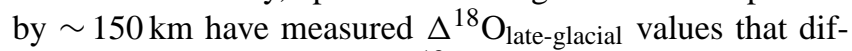
fer by $\sim 3 \%$ o (speleothem $\Delta^{18} \mathrm{O}_{\text {late-glacial }}-5.7 \pm 0.4 \%$ oversus groundwater $\Delta^{18} \mathrm{O}_{\text {late-glacial }}$ of $-2.8 \pm 1.0 \%$; Fleitmann et al., 2009; Arslan et al., 2013, 2015). While the locations of the groundwater and speleothem records differ, the compiled data suggest that groundwater and speleothem $\Delta^{18} \mathrm{O}_{\text {late-glacial }}$ values may capture different $\Delta^{18} \mathrm{O}_{\text {late-glacial }}$ values under similar climate conditions.

A number of potential processes could bias the preservation of precipitation isotope composition in ice core, speleothem or groundwater archives (Wang et al., 2001; Thompson et al., 2006; Edmunds, 2009). For example, groundwater and speleothem archives preserve only the isotope record of precipitation that traverses the vadose zone. Recent global analyses of paired precipitation-groundwater isotope compositions show that winter (extratropics) and wet season (tropics) precipitation contributes disproportionately to recharge (Jasechko et al., 2014), meaning that paleoclimate records may be more sensitive to changes to winter and wet seasons than summer or dry season (Vogel et al., 1963; Simpson et al., 1972; Grabczak et al., 1984; Harrington et al., 2002; Jones et al., 2000; Darling, 2004; Partin et al., 2012). Similarly, groundwater isotope records are unlikely to represent constant and continuous recharge fluxes during the lateHolocene or the late-glacial (McIntosh et al., 2012). Modern groundwater recharge fluxes are highest in humid climates (Wada et al., 2010). Groundwater $\delta^{18} \mathrm{O}$ records only represent precipitation that recharges aquifers, meaning that groundwater-based $\Delta^{18} \mathrm{O}_{\text {late-glacial }}$ values could be biased to subintervals (e.g., interstadials, pluvial periods) within the late-Holocene and late-glacial intervals when recharge fluxes were at local maxima. Speleothem records may be further complicated by processes impacting the timing of calcite precipitation. Recent modelling suggests that calcite precipitation in caves located outside of the tropics is greatest during the cool season and reduced during summer months due to changes in ventilation, meaning that higher latitude speleothems record oxygen isotope compositions biased to cool season climate change (James et al., 2015). Other recent work suggests that speleothem $\delta^{18} \mathrm{O}$ data may be impacted by disequilibrium isotope effects (Asrat et al., 2008; Daëron et al., 2011; Kluge and Affek, 2012; Kluge et al., 2013) or by partial evaporation of drip waters resulting in ${ }^{18} \mathrm{O}-$ enrichment (e.g., Cuthbert et al., 2014a) and greater fractionation due to evaporative cooling (Cuthbert et al., 2014b), potentially obscuring the preservation of primary precipitation isotope contents in the speleothem record. Compiled ice core records may have been influenced by post-depositional exchanges of ice with atmospheric vapour (Steen-Larsen et al., 2014). The impact of atmospheric vapour exchanges on ice core isotope records remains poorly understood. Potential biases in the preservation of precipitation $\delta^{18} \mathrm{O}$ differ among groundwater, glacial ice, and speleothem records, meaning that co-located records of differing record-type may preserve different $\Delta^{18} \mathrm{O}_{\text {late-glacial values under similar climate }}$ conditions. Finally, all proxy records may be impacted by past changes in the seasonality of precipitation, which can substantially impact annual precipitation $\delta^{18} \mathrm{O}$ values (e.g., Werner et al., 2000).

We cannot rule out the possibility that changes in seasonal biases of proxy record preservation occurred between the late-glacial and the late-Holocene and have impacted measured $\Delta^{18} \mathrm{O}_{\text {late-glacial }}$ values. Further, the chronologies of groundwaters and ice core records have uncertainties on the order of thousands of years, meaning that the time intervals used to calculate measured $\Delta^{18} \mathrm{O}_{\text {late-glacial values }}$ may be inaccurate. However, the plateauing of isotope content observed in most regional aquifers for 0-5000 years before present and for $>20000$ years before present supports our interpreting these data as records of late-glacial to late-Holocene isotopic shifts (see figures in the Supplement). Notwithstanding potential $\delta^{18} \mathrm{O}$ preservation biases and chronology uncertainties, the global data synthesized here show patterns consistent with the enhanced distillation of advected air masses originating as (sub)tropical ocean evaporate and undergoing progressive, poleward rainout under cooler-than-modern late-glacial temperatures.

\subsection{Simulated $\Delta^{18} \mathrm{O}_{\text {late-glacial values }}$}

Simulated precipitation $\Delta^{18} \mathrm{O}_{\text {late-glacial }}$ values from five general circulation models are presented in Fig. 5. At least four of the five models agree on the sign of simulated $\Delta^{18} \mathrm{O}_{\text {late-glacial }}$ values - that is values consistently above or consistently below zero - for $68.8 \%$ of grid cells covering Earth's surface $(68.7 \%$ of over-ocean areas and $68.9 \%$ of over land areas; multi-model calculation completed using three of four models as a threshold at high-latitudes where IsoGSM data were unavailable). Simulated $\Delta^{18} \mathrm{O}_{\text {late-glacial }}$ values are consistently negative over the North Atlantic Ocean and the Fennoscandian and Laurentide ice sheets and consistently positive over most of the tropical oceans, whereas poorer agreement is found over tropical land surfaces. The negative simulated $\Delta^{18} \mathrm{O}_{\text {late-glacial values over the }}$ Northern Hemisphere ice sheets and North Atlantic are likely driven by the difference in ice sheet topography and sea ice cover, between the late-glacial and pre-industrial cli- 


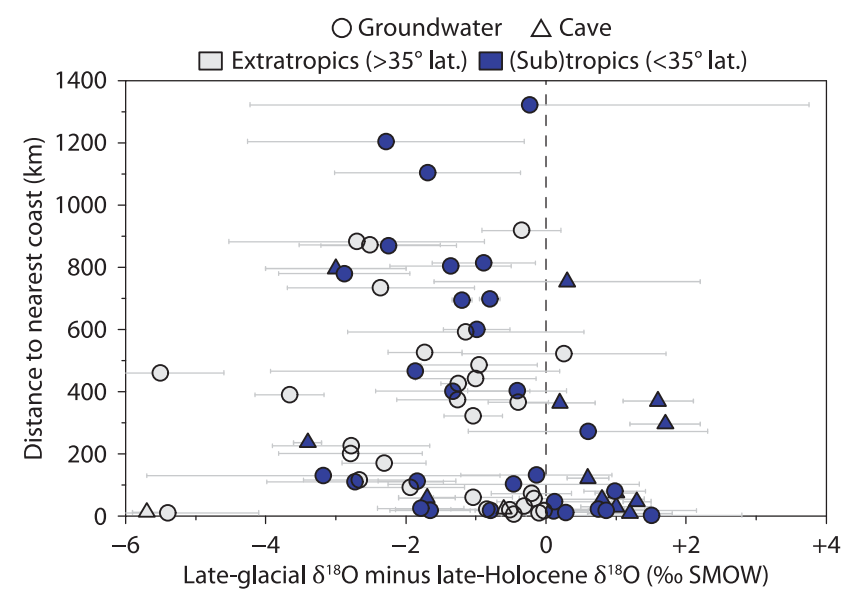

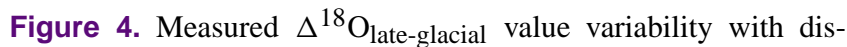
tance to the nearest coast $\left(\Delta^{18} \mathrm{O}_{\text {late-glacial }}=\delta^{18} \mathrm{O}_{\text {late-glacial }}-\right.$ $\left.\delta^{18} \mathrm{O}_{\text {late-Holocene }}\right)$. Tropical and subtropical locations are shown in deep blue $\left(<35^{\circ}\right.$ absolute latitude), extra-tropical sites are shown in light grey $\left(>35^{\circ}\right.$ absolute latitude). The shape of each point corresponds to groundwater and ground ice (circles) or cave calcite (i.e., speleothems; triangles). Error bars mark one standard deviation from the mean.

mate. The late-glacial to late-Holocene change in ice sheet topography and sea ice cover impacted surface temperatures, which were more than $\sim 20^{\circ} \mathrm{C}$ cooler over most of present-day Canada during the last glacial maximum (Fig. 1). Cooler temperatures in conjunction with ice sheet topography (> $3000 \mathrm{~m}$ elevations; e.g., Peltier, 1994) enhanced Rayleigh distillation for air masses transecting Northern Hemisphere ice sheets, as evidenced by systematically low measured and simulated $\delta^{18} \mathrm{O}_{\text {late-glacial }}$ values in these regions (Figs. 2, 3 and 5).

A comparison of simulated $\Delta^{18} \mathrm{O}_{\text {late-glacial }}$ values over tropical Africa, South America and Oceania shows intermodel disagreement (Fig. 5). Different tropical simulated $\Delta^{18} \mathrm{O}_{\text {late-glacial values among the models reflect the different }}$ isotopic parameterizations, inter-model spread in simulated precipitation rates, and seawater $\delta^{18} \mathrm{O}$ specifications used in each model (Supplement). Inter-model spread in simulated $\Delta^{18} \mathrm{O}_{\text {late-glacial }}$ values in some regions highlights the importance of this global synthesis of measured $\Delta^{18} \mathrm{O}_{\text {late-glacial }}$ values as a constraint for isotope-enabled climate simulations. Another potential source for the model disagreement is introduced by the different ice-sheet topography used in each model. CAM3Iso, IsoGSM and LMDZ4 used Ice 5G (Peltier, 1994) as advised for PMIP2 (Braconnot et al., 2007), whereas the GISSE2 replaces Ice 5G Laurentide ice with that of Licciardi et al. (1999) and ECHAM5-wiso uses ice topography from PMIP3 (Braconnot et al., 2007, 2012; PMIP3 follows ice sheet topography blended from multiple ice sheet reconstructions: Argus and Peltier, 2010; Toscano et al., 2011). Ice sheet topography is an important driver of simulated tem- perature, precipitation and atmospheric circulation during the last glacial maximum (e.g., Justino et al., 2005; Pausata et al., 2011b; Ullman et al., 2014). Therefore, it is likely that inter-model differences in paleo-ice sheet topographies impacts atmospheric circulation and thus high latitude simulated $\Delta^{18} \mathrm{O}_{\text {late-glacial }}$ values reported in this study (Fig. 5).

Differences in the specification of initial seawater $\delta^{18} \mathrm{O}$ may also lead to inter-model differences in simulated

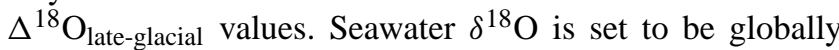
homogenous in CAM3Iso, IsoGSM and LMDZ4, and heterogeneous in ECHAM5-wiso (using modern gridded seawater $\delta^{18} \mathrm{O}$ heterogeneity of LeGrande and Schmidt, 2006) and GISSE2-R (coupled atmosphere-ocean model; seawater $\delta^{18} \mathrm{O}$ is calculated by the ocean model). Including surface ocean $\delta^{18} \mathrm{O}$ heterogeneities in model simulations impacts land precipitation $\delta^{18} \mathrm{O}$ by up to $\sim 1.5 \%$ o relative to simulations with homogenous seawater $\delta^{18} \mathrm{O}$ (LeGrande and Schmidt, 2006). However, different seawater $\delta^{18} \mathrm{O}$ specifications cannot account for all inter-model differences in simulated $\Delta^{18} \mathrm{O}_{\text {late-glacial values. }}$

The models also show deficiencies in simulating measured $\Delta{ }^{18} \mathrm{O}_{\text {late-glacial }}$ values in the tropics, particularly over tropical Africa. This finding could, in part, relate to the high sensitivity of precipitation $\delta^{18} \mathrm{O}$ to convective parameterizations (Lee et al., 2009; Field et al., 2014), although future research is required to test this. Another reason may be that the measured $\Delta^{18} \mathrm{O}_{\text {late-glacial }}$ integrates the hydroclimatological signal over multi-millennial timescales, whereas the simulated $\Delta^{18} \mathrm{O}_{\text {late-glacial }}$ values explicitly explore last glacial maximum and pre-industrial/present-day climate conditions. The smeared temporal resolution of groundwater-based measured $\Delta{ }^{18} \mathrm{O}_{\text {late-glacial }}$ values due to storage and mixing in the aquifer precludes an ideal comparison of measured versus

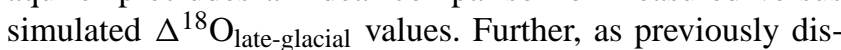
cussed in Sect. 3.1, the measured $\Delta^{18} \mathrm{O}_{\text {late-glacial values are }}$ susceptible to a number of potential biases that may obscure the magnitude and direction of late-glacial to late-Holocene precipitation $\delta^{18} \mathrm{O}$ changes. Notwithstanding, models correctly simulate the sign of measured $\Delta^{18} \mathrm{O}_{\text {late-glacial }}$ values (i.e., positive or negative) in the extratropics more frequently than in the tropics. Better agreement in the sign of simulated versus measured $\Delta^{18} \mathrm{O}_{\text {late-glacial values in the extra- }}$ tropics compared to the tropics is likely linked to the substantial changes to extra-tropical ice-sheet topography and seaice cover between the two climate states in northern North America and Europe. Substantial changes to Northern Hemisphere ice volumes between the late-glacial and the lateHolocene likely enhanced upwind distillation of air masses leading to high-magnitude, negative $\Delta^{18} \mathrm{O}_{\text {late-glacial values }}$ that are well captured by the climate simulations. However,

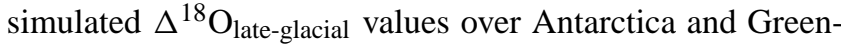
land show large inter-model spread, suggesting that modelbased interpretations of polar ice core records may vary widely among different atmospheric models. 

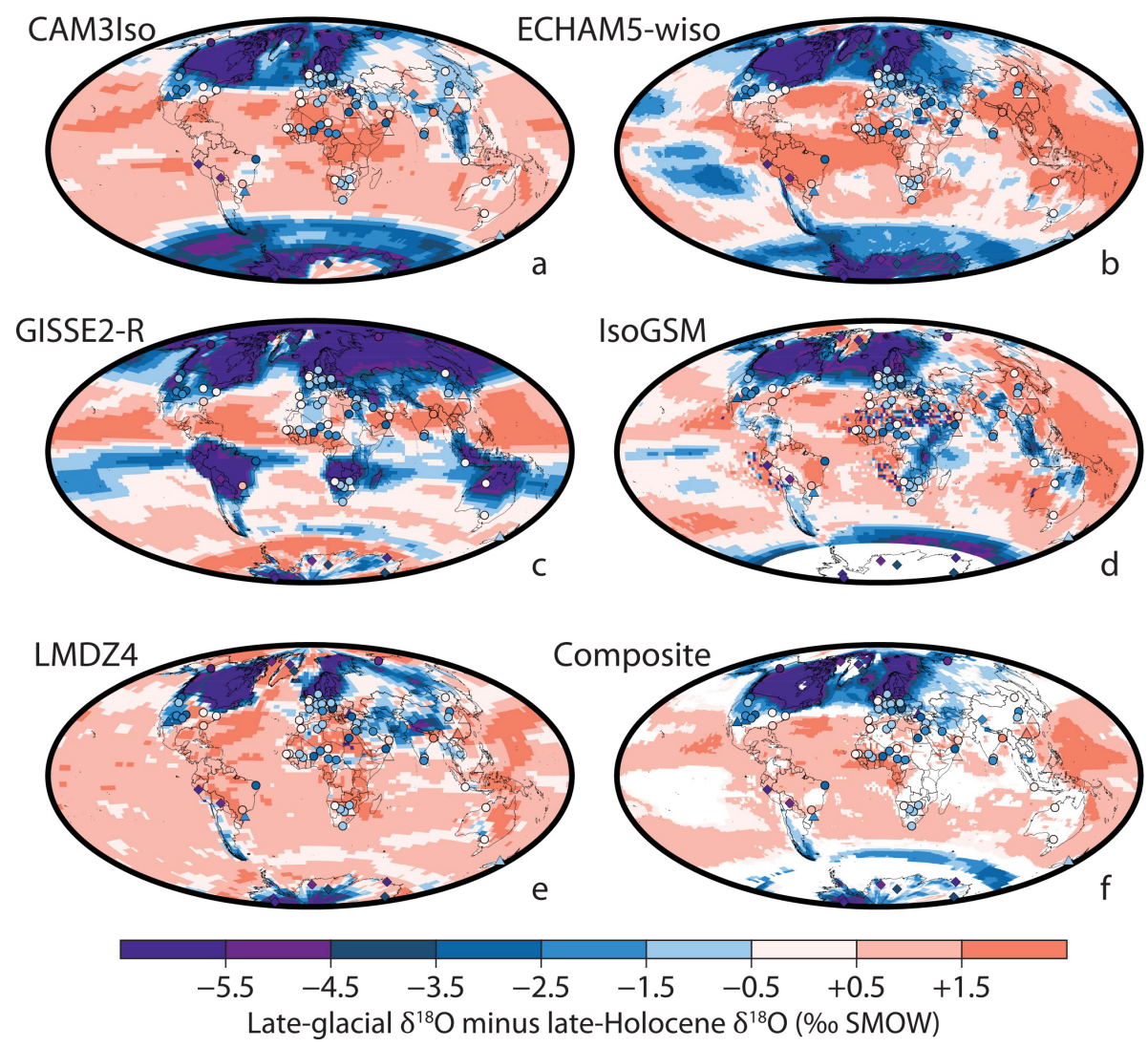

Figure 5. Simulated precipitation $\delta^{18} \mathrm{O}$ differences between the last glacial maximum and pre-industrial time periods (i.e., $\left.\delta^{18} \mathrm{O}_{\text {last glacial maximum }}-\delta^{18} \mathrm{O}_{\text {pre-industrial }}\right)$ from five general circulation models: CAM3iso, ECHAM5-wiso, GISSE2-R, IsoGSM and LMDZ4 (Yoshimura et al., 2003; Legrande and Schmidt, 2008, 2009; Risi et al., 2010a; Noone and Sturm, 2010; Pausata et al., 2011a; Werner et al., 2011). Circles (groundwater), triangles (speleothems) and diamonds (ice cores) show measured $\Delta^{18} \mathrm{O}_{\text {late-glacial values from }}$ paleoclimate proxy records (Fig. 1, original data presented in Tables S2-S5). The panel entitled "Composite" shows the multi-model ensem-

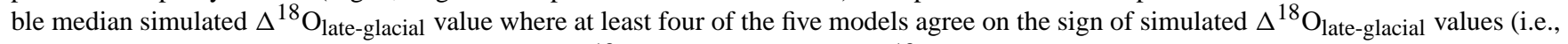
positive or negative; all five model simulations of $\delta^{18} \mathrm{O}_{\text {last glacial maximum }}-\delta^{18} \mathrm{O}_{\text {pre-industrial were used to calculate multi-model median }}$ shown in "Composite").

\subsection{Regional measured and simulated $\Delta^{18} \mathrm{O}_{\text {late-glacial }}$ values}

\subsubsection{Australia and Oceania}

Measured $\Delta^{18} \mathrm{O}_{\text {late-glacial }}$ values from Australia and Oceania fall between -1 and $+1 \%$ o (Fig. 2). Australian climate during the last glacial time period was more arid (Nanson et al., 1992), dustier (Chen et al., 1993) and cooler (Miller et al., 1997) than present day. Simulated $\Delta^{18} \mathrm{O}_{\text {late-glacial }}$ values across Australia are variable among the five models. Measured $\Delta^{18} \mathrm{O}_{\text {late-glacial }}$ values across Oceania have been attributed to temporal changes in the strength of monsoons and convective rains (Aggarwal et al., 2004; Partin et al., 2007; Williams et al., 2010) potentially impacted by late-glacial to late-Holocene shifts in the position of the intertropical convergence zone (Lewis et al., 2010, 2011).

\subsubsection{Southeast Asia}

Measured $\Delta^{18} \mathrm{O}_{\text {late-glacial }}$ values from southeastern Asia range from -2.3 to $+1.7 \%$. The highest regional measured $\Delta^{18} \mathrm{O}_{\text {late-glacial values are found in Bangladesh (mea- }}$ sured $\Delta^{18} \mathrm{O}_{\text {late-glacial }}$ of $+1.5 \pm 1.3 \%$; Aggarwal et al., 2000) and in central and southeastern China (measured $\Delta \Delta^{18} \mathrm{O}_{\text {late-glacial }}$ of +0.3 to $+1.7 \%$; Wang et al., 2001; Yuan et al., 2004; Dykoski et al., 2005; Cai et al., 2010; Yang et al., 2010). General circulation models have positive simulated $\Delta^{18} \mathrm{O}_{\text {late-glacial }}$ values near to the Chinese coasts, but are more variable across western and northern China (Fig. 5). Chinese speleothem records show near-zero or positive measured $\Delta^{18} \mathrm{O}_{\text {late-glacial }}$ values interpreted to reflect the reduced strength of the East Asian (Wang et al., 2001; Dykoski et al., 2005; Cosford et al., 2008) or Indian monsoons (Pausata et al., 2011a). Further research suggests that Chinese speleothem $\delta^{18} \mathrm{O}$ variations reflect changes to regional moisture sources and the intensity or provenance of atmo- 
spheric transport pathways (LeGrande and Schmidt, 2009; Dayem et al., 2010; Lewis et al., 2010; Maher and Thompson, 2012; Caley et al., 2014b; Tan, 2014).

North China Plain groundwaters have high-magnitude, negative $\Delta^{18} \mathrm{O}_{\text {late-glacial }}$ values (measured $\Delta^{18} \mathrm{O}_{\text {late-glacial }}$ of $-2.3 \pm 0.6 \%$; Chen et al., 2003) compared to coastal, more southerly counterparts. Combining the negative measured $\Delta^{18} \mathrm{O}_{\text {late-glacial }}$ in northern China (Chen et al., 2003; Ma et al., 2008; Currell et al., 2012; Li et al., 2015) with the positive measured $\Delta^{18} \mathrm{O}_{\text {late-glacial }}$ values in central and southeastern China (Wang et al., 2001; Yuan et al., 2004; Dykoski et al., 2005; Cai et al., 2010; Yang et al., 2010) reveals a south-tonorth decrease from positive (south) to negative (north) mea-

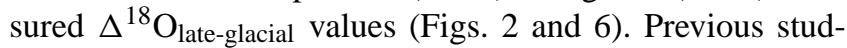
ies of modern precipitation have identified increasing precipitation $\delta^{18} \mathrm{O}$ values from the coast to inland China during the wet season, sharply contrasting spatial patterns expected from Rayleigh distillation (Aragúas-Aragúas et al., 1998). A more recent work suggests that low wet-season precipitation $\delta^{18} \mathrm{O}$ values over southern China are controlled by the deflection of westerlies around the Tibetan Plateau, whereas precipitation $\delta^{18} \mathrm{O}$ values over northern China are controlled by local-scale rainfall and below-cloud raindrop evaporation (Lee et al., 2012). Therefore, measured $\Delta^{18} \mathrm{O}_{\text {late-glacial }}$ values from southern China may reflect changes to atmospheric circulation at broader spatial scales, whereas measured $\Delta^{18} \mathrm{O}_{\text {late-glacial }}$ values from northern China may indicate changes to more localized atmospheric conditions impacting processes such as raindrop evaporation in addition to meso- and synoptic-scale circulation changes.

\subsubsection{Africa}

Measured $\Delta{ }^{18} \mathrm{O}_{\text {late-glacial values from Africa range from }}$ -2.9 to $+0.1 \%$ o (Figs. 2 and 6). Sixteen of 17 measured $\Delta^{18} \mathrm{O}_{\text {late-glacial }}$ values from Africa are negative. Near-zero measured $\Delta^{18} \mathrm{O}_{\text {late-glacial values are generally found near to }}$ coasts (e.g., Senegal $\Delta^{18} \mathrm{O}_{\text {late-glacial of }}+0.1 \pm 0.8 \%$; Madioune et al., 2014), whereas higher magnitude, negative

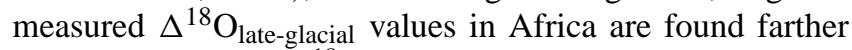
inland (e.g., Niger $\Delta^{18} \mathrm{O}_{\text {late-glacial values of }-2.3 \pm 2.0 \text { and }}$ $-2.9 \pm 0.9 \%$ : $\sim 800 \mathrm{~km}$ from the Atlantic coast). General circulation model $\Delta^{18} \mathrm{O}_{\text {late-glacial values show poor agree- }}$ ment with measured $\Delta^{18} \mathrm{O}_{\text {late-glacial }}$ over tropical Africa compared to model-measured comparisons for Europe and North America (Fig. 5), with positive simulated $\Delta^{18} \mathrm{O}_{\text {late-glacial }}$ values predicted over large parts of Africa where negative $\Delta^{18} \mathrm{O}_{\text {late-glacial }}$ values are measured. Figure 5 shows that Africa has the largest inter-model and model-measurement disagreements in the sign of $\Delta^{18} \mathrm{O}_{\text {late-glacial values of the con- }}$ tinents.

Northern African hydrological processes are influenced by interlinked controls such as meridional shifts in the position of the intertropical convergence zone (Arbuszewski et al., 2013) and the strength of Atlantic meridional overturning
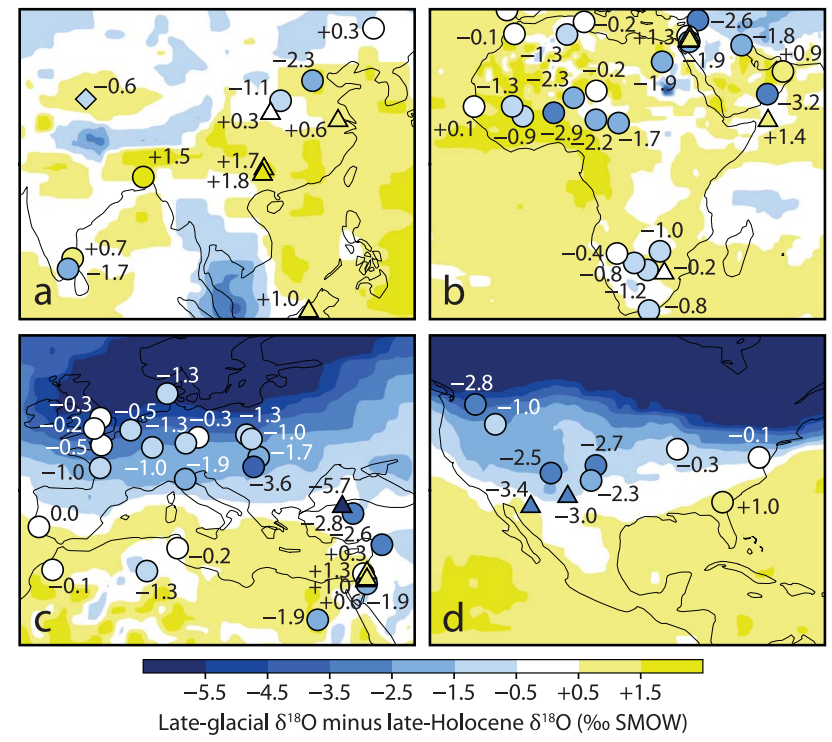

Figure 6. Regional proxy record $\Delta^{18} \mathrm{O}_{\text {late-glacial values for }}$ (a) southeastern Asia, (b) Africa, (c) Europe, and (d) the contiguous United States of America (where $\Delta^{18} \mathrm{O}_{\text {late-glacial }}=$ $\left.\delta^{18} \mathrm{O}_{\text {late-glacial }}-\delta^{18} \mathrm{O}_{\text {late-Holocene }}\right)$. The multi-model ensemble

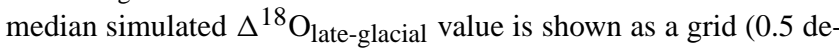
gree smoothing). Groundwater records are represented by circles, speleothems by triangles, and ice cores by diamonds, labels show measured $\Delta^{18} \mathrm{O}_{\text {late-glacial values for each individual record. }}$

circulation (Mulitza et al., 2008). Paleowater chemistry indicates that northern Africa was at least $2{ }^{\circ} \mathrm{C}$ cooler than today (Guendouz et al., 1998) and that westerly moisture transport was stronger than the present during the late-glacial (Sultan et al., 1997; Abouelmagd et al., 2012).

Tropical Africa was 2 to $4{ }^{\circ} \mathrm{C}$ cooler and more arid than present day at the last glacial maximum (Powers et al., 2005; Tierney et al., 2008). Early- and late-Holocene rainfall and isotope compositions were highly variable across Africa (Tierney et al., 2008, 2013; Schefuß et al., 2011; OttoBliesner et al., 2014). Tropical African rainfall originates from both Indian and Atlantic sources, with Atlantic-sourced moisture travelling across the Congo rainforest (Levin et al., 2009). Lower-than-modern continental moisture recycling during the late-glacial may partially explain negative measured $\Delta^{18} \mathrm{O}_{\text {late-glacial }}$ values across some regions of inland tropical Africa (e.g., Risi et al., 2013). Negative measured $\Delta^{18} \mathrm{O}_{\text {late-glacial }}$ values in tropical Africa could also be interpreted to reflect higher-than-modern upwind rainout during the late-glacial (see Risi et al., 2008, 2010b; Lee et al., 2009; Scholl et al., 2009; Lekshmy et al., 2014; SamuelsCrow et al., 2014); however, this explanation necessitates stronger-than-modern convection during the late-glacial, an explanation that would contradict the established coolerthan-modern land surface temperatures. Therefore, changes to atmospheric transport distances and vapour origins are 
more likely responsible for negative measured $\Delta^{18} \mathrm{O}_{\text {late-glacial }}$ values across tropical Africa (Lewis et al., 2010).

\subsubsection{Europe and the Mediterranean}

Measured $\Delta^{18} \mathrm{O}_{\text {late-glacial values across Europe, the Middle- }}$ East and the eastern Mediterranean range from -5.7 to $+1.3 \%$. Eighty percent of measured $\Delta^{18} \mathrm{O}_{\text {late-glacial values }}$ across these regions are negative. All five general circulation models agree on negative simulated $\Delta^{18} \mathrm{O}_{\text {late-glacial val- }}$ ues across Europe, consistent with the negative measured $\Delta^{18} \mathrm{O}_{\text {late-glacial }}$ values across the majority of Europe. Measured $\Delta^{18} \mathrm{O}_{\text {late-glacial }}$ values are generally higher in western Europe $(0.0$ to $-1.0 \%$ in Portugal, the United Kingdom and France) than in eastern Europe ( -1.0 to $-5.7 \%$ o in Poland, Hungary and Turkey; Stute and Deak, 1989; Le Gal La Salle et al., 1996; Darling et al., 1997; Barbecot et al., 2000; Zuber et al., 2004; Galego Fernandes and Carreira, 2008; Celle-Jeanton et al., 2009; Varsányi et al., 2011; Samborska et al., 2013; Arslan et al., 2013). This spatial pattern of $\Delta^{18} \mathrm{O}_{\text {late-glacial }}$ values is consistent with enhanced isotopic distillation of westerlies during the late-glacial due to coolerthan-modern final condensation temperatures.

High magnitude, negative measured $\Delta^{18} \mathrm{O}_{\text {late-glacial values }}$ are located in Turkey and Georgia south and east of the Black Sea $(-2.8 \pm 1.0$ to $-5.7 \pm 0.4 \%$; Fleitmann et al., 2009; Arslan et al., 2013; Melikadze et al., 2014). Westerly air mass trajectories distal to the Fennoscandian ice sheet topography may not have changed considerably since the lateglacial over western and central Europe (Rozanski, 1985; Loosli et al., 2001). Therefore, higher, near-zero measured $\Delta^{18} \mathrm{O}_{\text {late-glacial values in western Europe and lower, negative }}$ measured $\Delta^{18} \mathrm{O}_{\text {late-glacial values in eastern Europe indicate }}$ enhanced distillation of advected air masses during the lateglacial relative to the late-Holocene.

Changes to freeze-thaw conditions of the ground surface between the latter half of the last glacial time period and the modern climates may have impacted the seasonality of the fraction of precipitation recharging aquifers and thus $\Delta^{18} \mathrm{O}_{\text {late-glacial }}$ (Darling, 2004, 2011; Jasechko et al., 2014). Geomorphic evidence suggests permafrost covered portions of Hungary at the last glacial maximum, suggesting that land temperatures may have been up to $15^{\circ} \mathrm{C}$ cooler than present day (Fábián et al., 2014), a larger late-glacial to late-Holocene temperature shift than earlier, noble gasbased reconstructions $\left(5-7^{\circ} \mathrm{C}\right.$; Deák et al., 1987). European pollen records indicate that northern Europe was tundralike and that southern Europe was semi-arid during the last glacial maximum (Harrison and Prentice, 2003; Clark et al., 2012). The European late-glacial to late-Holocene transition from semi-arid deserts to temperate forests could have lowered $\Delta^{18} \mathrm{O}_{\text {late-glacial }}$ values as groundwater recharge ratios transitioned from more extreme winter-biased (e.g., semiarid lands during the late-glacial) to less extreme winter- biased groundwater recharge ratios (e.g., forests during lateHolocene; Jasechko et al., 2014).

\subsubsection{South America}

Measured $\Delta{ }^{18} \mathrm{O}_{\text {late-glacial values across South America range }}$ from -6.3 to $+0.6 \%$ (Figs. 2 and 6 ). The highestmagnitude, negative measured $\Delta^{18} \mathrm{O}_{\text {late-glacial }}$ values are found in Andean ice cores $\left(\Delta^{18} \mathrm{O}_{\text {late-glacial of }-4.6 \pm 1.0 \text { and }}\right.$ $-6.3 \pm 1.3$; Thompson et al., 1995, 1998). Here the importance of upstream convection upon modern Andean precipitation $\delta^{18} \mathrm{O}$ has been highlighted at inter-annual (Hoffmann et al., 2003; Vuille and Werner, 2005), seasonal (Vimeux et al., 2005; Samuels-Crow et al., 2014) and daily timescales (Vimeux et al., 2011). It is therefore possible that upstream convection controls past changes to Andean precipitation isotope compositions recorded in ice cores.

The measured groundwater $\Delta^{18} \mathrm{O}_{\text {late-glacial value located in }}$ eastern Brazil is $-2.7 \pm 1.3 \%$ o (Salati et al., 1974). Eastern Brazil was $5^{\circ} \mathrm{C}$ cooler than today during the latter half of the last glacial period (Stute et al., 1995b). Four of the five general circulation models simulate positive $\Delta^{18} \mathrm{O}_{\text {late-glacial }}$ values across eastern Brazil (Fig. 5), highlighting a difference between simulated and measured $\Delta^{18} \mathrm{O}_{\text {late-glacial values }}$ in parts of the tropics. The negative measured $\Delta^{18} \mathrm{O}_{\text {late-glacial }}$ value in eastern Brazil has been previously interpreted to reflect higher-than-modern precipitation during the last glacial time period (Salati et al., 1974). Lewis et al. (2010) show that localized rainfall governs precipitation $\delta^{18} \mathrm{O}$ in eastern Brazil. Modern precipitation $\delta^{18} \mathrm{O}$ values are lowest in eastern Brazil when precipitation rates are at a maximum. Extending Lewis et al.'s interpretation linking local precipitation amount to precipitation $\delta^{18} \mathrm{O}$ would suggest that the negative measured $\Delta^{18} \mathrm{O}_{\text {late-glacial }}$ value found in eastern Brazil may indeed record wetter-than-modern conditions during the late-glacial as proposed by Salati et al. (1974). Further, disagreement between measured and simulated $\Delta^{18} \mathrm{O}_{\text {late-glacial }}$ in eastern Brazil highlights the need to critically evaluate climate model performance in regions where the precipitation amount is closely correlated with precipitation $\delta^{18} \mathrm{O}$.

\subsubsection{North America}

Measured $\Delta^{18} \mathrm{O}_{\text {late-glacial }}$ from North American proxy records range from -5.5 to $+1.0 \%$. Canadian records of groundwater recharge that took place beneath the Laurentide ice sheet are not included in this synthesis ("subglacial recharge"; Grasby and Chen, 2005; Ferguson et al., 2007; McIntosh et al., 2012; Ferguson and Jasechko, 2015). These records were excluded because the subglacial meltwaters that recharged aquifers likely reflect precipitation that fell elsewhere on the paleo-ice sheet, potentially complicating the comparison of groundwater isotope compositions for the late-Holocene and last glacial time period. 


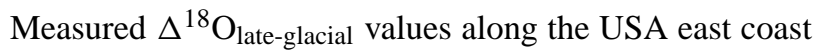
show the highest, positive values in Georgia (latitude: $32^{\circ} \mathrm{N}$; measured $\Delta^{18} \mathrm{O}_{\text {late-glacial }}+1.0 \%$; Clark et al., 1997), decreasing northward to near-zero measured $\Delta^{18} \mathrm{O}_{\text {late-glacial }}$ values in coastal Maryland (latitude $39^{\circ} \mathrm{N}$; measured $\Delta^{18} \mathrm{O}_{\text {late-glacial }}$ of $-0.1 \pm 0.4 \%$; Aeschbach-Hertig et al., 2002). Decreasing $\Delta^{18} \mathrm{O}_{\text {late-glacial }}$ values with increasing latitude along the USA east coast may be explained in part by the isotopic distillation of air masses advected northward from the subtropics under cooler-than-modern final atmospheric condensation temperatures. Indeed, paleoclimate records indicate that Maryland was more arid and as much as $9-12{ }^{\circ} \mathrm{C}$ cooler during the late-glacial relative to the lateHolocene (Purdy et al., 1996; Aeschbach-Hertig et al., 2002; Plummer et al., 2012). In addition to temperature change, late-glacial precipitation isotope compositions along eastern USA coastline were likely impacted by the lower-thanmodern late-glacial sea levels, which changed overland atmospheric transport distances between the late-glacial and late-Holocene (Clark et al., 1997; Aeschbach-Hertig et al., 2002; Tharammal et al., 2013).

Measured $\Delta^{18} \mathrm{O}_{\text {late-glacial }}$ values in the central and southwestern USA have the highest magnitude, negative measured $\Delta^{18} \mathrm{O}_{\text {late-glacial }}$ values of temperate North America, ranging from -1.0 to $-3.4 \%$. Central and southwestern USA measured $\Delta^{18} \mathrm{O}_{\text {late-glacial }}$ values contrast the positive measured $\Delta^{18} \mathrm{O}_{\text {late-glacial }}$ values found along the eastern USA coast at similar latitudes. Consistently negative $\Delta^{18} \mathrm{O}_{\text {late-glacial }}$ values in central and southwest USA suggest that advected moisture to the region underwent greater upstream air mass distillation during the late-glacial than under modern climate. Pollen, vadose zone and groundwater records show that late-glacial southwestern USA was $\sim 4{ }^{\circ} \mathrm{C}$ cooler, had greater groundwater recharge fluxes, and had more widespread forests than present day (Stute et al., 1992, 1995a; Scanlon et al., 2003; Williams, 2003). Negative measured $\Delta^{18} \mathrm{O}_{\text {late-glacial values }}$ found in the southwest USA have been ascribed to lowerthan-modern summer precipitation (New Mexico, Phillips et al., 1986), latitudinal shifts in the positions of the polar jet stream and the intertropical convergence zone (New Mexico, Asmerom et al., 2010) and changes to over-ocean humidity, temperature or moisture sources (Idaho, Schlegel et al., 2009). Wagner et al. (2010) interpret decreases to southwestern precipitation $\delta^{18} \mathrm{O}$ to reflect cooler and more-humid conditions. Extending this interpretation to negative measured $\Delta^{18} \mathrm{O}_{\text {late-glacial }}$ values found across the southwestern USA values supports earlier conclusions that the region was cooler and more humid than today during the late-glacial, possibly linked to changes in air mass trajectories and moisture sources (Asmerom et al., 2010; Wagner et al., 2010). Simulated $\Delta^{18} \mathrm{O}_{\text {late-glacial values across North America closely }}$ match spatial patterns of measured $\Delta^{18} \mathrm{O}_{\text {late-glacial }}$ synthesized in this study. Strong, multi-model agreement with measured $\Delta^{18} \mathrm{O}_{\text {late-glacial }}$ patterns supports continued application of isotope-enabled general circulation models when interpreting North American precipitation isotope proxy records.

\section{Conclusions}

While changes to the isotope content of precipitation between the last glacial time period and more recent times has been widely documented, few studies have synthesized these dispersed data to explore the global patterns of $\delta^{18} \mathrm{O}$ change driven by past shifts to regional climate. In this study we compile groundwater, speleothem, ice core and ground ice records of $\delta^{18} \mathrm{O}$ shifts between the late-glacial (20 to $\sim 50$ thousand years ago) and the late-Holocene (within the past 5000 years). Late-glacial to late-Holocene $\delta^{18} \mathrm{O}$ shifts range from $-7.1 \%$ (i.e., $\delta^{18} \mathrm{O}_{\text {late-glacial }}<\delta^{18} \mathrm{O}_{\text {late-Holocene) }}$ to +1.7 (i.e., $\delta^{18} \mathrm{O}_{\text {late-glacial }}>\delta^{18} \mathrm{O}_{\text {late-Holocene }}$ ). Aquifers with positive measured $\Delta^{18} \mathrm{O}_{\text {late-glacial }}$ values ( $23 \%$ of records) are most common along the subtropical coasts. The majority $(77 \%)$ of measured $\Delta^{18} \mathrm{O}_{\text {late-glacial }}$ values are negative, with the highest magnitude differences between $\delta^{18} \mathrm{O}_{\text {late-glacial }}$ and $\delta^{18} \mathrm{O}_{\text {late-Holocene }}$ observed at high latitudes and far from coasts. This spatial pattern suggests that isotopic distillation of advected air masses was greater during the late-glacial than under present climate, likely due to the non-linear nature of Rayleigh distillation, accentuated by larger glacialinterglacial atmospheric temperature changes at the poles relative to lower latitudes. Regionally divergent precipitation $\delta^{18} \mathrm{O}$ responses to the $\sim 4{ }^{\circ} \mathrm{C}$ of global warming occurring between the late-glacial and the late-Holocene suggest that continued monitoring of modern precipitation isotope contents may prove useful for detecting hydrologic changes due to ongoing, human-induced climate change. Future paleoprecipitation proxy record $\delta^{18} \mathrm{O}$ research can use these new global maps of $\Delta^{18} \mathrm{O}_{\text {late-glacial }}$ records to target and prioritize field sites. In the near term, a global compilation of large lake sediment isotope records that accounts for paleoevaporative isotope effects could enhance spatial coverage of interglacial-glacial $\delta^{18} \mathrm{O}$ shifts.

General circulation models agree on the sign and magnitude of terrestrial precipitation $\Delta^{18} \mathrm{O}_{\text {late-glacial values better }}$ in the extra-tropics than in the tropics. Differences in simulated precipitation isotope composition changes amongst the models might be linked to different parameterizations of seawater $\delta^{18} \mathrm{O}$, glacial topography and convective rainfall, however, these hypotheses require further testing. Future model research should focus on quantifying the relative roles of inter-model spread in the simulated climate versus the isotopic response to climate change on resulting simulated precipitation $\delta^{18} \mathrm{O}$. This would provide guidelines to interpret model-data isotopic differences and to identify what aspects climate models have greatest difficulties capturing.

\section{The Supplement related to this article is available online at doi:10.5194/cp-11-1375-2015-supplement.}


Acknowledgements. We acknowledge support from the University of Calgary's Open Access Author's Fund, an NSERC Discovery Grant held by S. Jasechko, the UNESCO IGCP-618 project (Paleoclimate information obtained from past-recharged groundwater), the G@GPS network, and the Caswell Silver Foundation. We are thankful for the assessments of Ph. Négrel and two anonymous reviewers. We also thank T. W. D. Edwards for insightful comments on an earlier version of the manuscript.

Edited by: V. Masson-Delmotte

\section{References}

Abouelmagd, A., Sultan, M. Milewski, A., Kehew, A. E., Sturchio, N. C., Soliman, F., Krishnamurthy, R. V., and Cutrim, E.: Toward a better understanding of palaeoclimatic regimes that recharged the fossil aquifers in North Africa: Inferences from stable isotope and remote sensing data, Palaeogeogr. Palaeocl., 329-330, 137149, 2012.

Aeschbach-Hertig, W., Stute, M., Clark, J. F., Reuter, R. F., and Schlosser, P.: A paleotemperature record derived from dissolved noble gases in groundwater of the Aquia Aquifer (Maryland, USA), Geochim. Cosmochim. Ac., 66, 797-817, 2002.

Aggarwal, P. K., Basu, A. R., Poreda, R. J., Kulkarni, K. M., Froehlich, K., Tarafdar, S. A., Ali, M., Ahmed, N., Hussain, A., Rahman, M., and Ahmed, S. R.: A report on isotope hydrology of groundwater in Bangladesh: implications for characterization and mitigation of arsenic in groundwater, International Atomic Energy Agency, Department of Technical Co-operation, Vienna (Austria), 65 pp., 2000.

Aggarwal, P. K., Fröhlich, K., Kulkarni, K. M., and Gourcy, L. L.: Stable isotope evidence for moisture sources in the Asian summer monsoon under present and past climate regimes, Geophys. Res. Lett., 31, L08203, doi:10.1029/2004GL019911, 2004.

Aichner, B., Feakins, S. J., Lee, J. E., Herzschuh, U., and Liu, X.: High-resolution leaf wax carbon and hydrogen isotopic record of the late Holocene paleoclimate in arid Central Asia, Clim. Past, 11, 619-633, doi:10.5194/cp-11-619-2015, 2015.

Akouvi, A., Dray, M., Violette, S., de Marsily, G., and Zuppi, G. M.: The sedimentary coastal basin of Togo: example of a multilayered aquifer still influenced by a palaeo-seawater intrusion, Hydrogeology J., 16, 419-436, 2008.

Anderson, L., Abbott, M. B., and Finney, B. P.: Holocene climate inferred from oxygen isotope ratios in lake sediments, central Brooks Range, Alaska, Quaternary Res., 55, 313-321, 2001.

Annan, J. D. and Hargreaves, J. C.: A new global reconstruction of temperature changes at the Last Glacial Maximum, Clim. Past, 9, 367-376, doi:10.5194/cp-9-367-2013, 2013.

Aragúas-Aragúas, L., K. Froehlich, and Rozanski, K.: Stable isotope composition of precipitation over Southeast Asia, J. Geophys. Res., 103, 721-742, 1998.

Arbuszewski, J. A., Cléroux, C., Bradtmiller, L., and Mix, A.: Meridional shifts of the Atlantic intertropical convergence zone since the Last Glacial Maximum, Nat. Geosci., 6, 959-962, 2013.

Argus, D. F. and Peltier, W. R.: Constraining models of postglacial rebound using space geodesy: a detailed assessment of model ICE-5G (VM2) and its relatives, Geophys. J. Int., 181, 697-723, 2010 .
Arslan, S., Yazicigil, H., Stute, M., and Schlosser, P.: Environmental isotopes and noble gases in the deep aquifer system of Kazan Trona Ore Field, Ankara, central Turkey and links to paleoclimate, Quaternary Res., 79, 292-303, 2013.

Arslan, S., Yazicigil, H., Stute, M., Schlosser, P., and Smethie, W. M.: Analysis of groundwater dynamics in the complex aquifer system of Kazan Trona, Turkey, using environmental tracers and noble gases, Hydrogeol. J., 23, 175-194, 2015.

Asmerom, Y., Polyak, V. J., and Burns, S. J.: Variable winter moisture in the southwestern United States linked to rapid glacial climate shifts, Nat. Geosci., 3, 114-117, 2010.

Asrat, A., Baker, A., Leng, M., Gunn, J., and Umer, M.: Environmental monitoring in the Mechara caves, Southeastern Ethiopia: implications for speleothem palaeoclimate studies, Int. J. Speleol., 37, 207-220, 2008.

Bakari, S. S., Aagaard, P., Vogt, R. D., Ruden, F., Brennwald, M. S., Johansen, I., and Gulliksen, S.: Groundwater residence time and paleorecharge conditions in the deep confined aquifers of the coastal watershed, South-East Tanzania, J. Hydrol., 466-467, 127-140, 2012.

Bar-Matthews, M., Ayalon, A., Gilmour, M., Matthews, A., and Hawkesworth, C.: Sea-land oxygen isotopic relationships from planktonic foraminifera and speleothems in the Eastern Mediterranean region and their implication for paleorainfall during interglacial intervals, Geochim. Cosmochim. Ac., 67, 3181-3199, 2003.

Barbecot, F., Marlin, C., Gibert, E., and Dever, L.: Hydrochemical and isotopic characterisation of the Bathonian and Bajocian coastal aquifer of the Caen area (northern France), Appl. Geochem., 15, 791-805, 2000.

Beuning, K. R., Kelts, K., Russell, J. M., and Wolfe, B. B.: Reassessment of Lake Victoria-Upper Nile River paleohydrology from oxygen isotope records of lake-sediment cellulose, Geology, 30, 559-562, 2002.

Bowen, G. J. and Wilkinson, B.: Spatial distribution of $\delta^{18} \mathrm{O}$ in meteoric precipitation, Geology, 30, 315-318, 2002.

Braconnot, P., Otto-Bliesner, B., Harrison, S., Joussaume, S., Peterchmitt, J.-Y., Abe-Ouchi, A., Crucifix, M., Driesschaert, E., Fichefet, Th., Hewitt, C. D., Kageyama, M., Kitoh, A., Laîné, A., Loutre, M.-F., Marti, O., Merkel, U., Ramstein, G., Valdes, P., Weber, S. L., Yu, Y., and Zhao, Y.: Results of PMIP2 coupled simulations of the Mid-Holocene and Last Glacial Maximum Part 1: experiments and large-scale features, Clim. Past, 3, 261277, doi:10.5194/cp-3-261-2007, 2007.

Braconnot, P., Harrison, S. P., Kageyama, M., Bartlein, P. J., Masson-Delmotte, V., Abe-Ouchi, A. Otto-Bliesner, B., and Zhao, Y.: Evaluation of climate models using palaeoclimatic data, Nature Climate Change, 2, 417-424, 2012.

Burg, A., Zilderbrand, M., and Yechieli, Y.: Radiocarbon variability in groundwater in an extremely arid zone-the Arava Valley, Israel, Radiocarbon, 55, 963-978, 2013.

Cai, Y., Tan, L., Cheng, H., An, Z., Edwards, R. L., Kelly, M. J., Kong, X., and Wang, X.: The variation of summer monsoon precipitation in central China since the last deglaciation, Earth Planet. Sci. Lett., 291, 21-31, 2010.

Caley, T., Roche, D. M., Waelbroeck, C., and Michel, E.: Oxygen stable isotopes during the Last Glacial Maximum climate: perspectives from data-model (iLOVECLIM) comparison, Clim. Past, 10, 1939-1955, doi:10.5194/cp-10-1939-2014, 2014a. 
Caley, T., Roche, D. M., and Renssen, H.: Orbital Asian summer monsoon dynamics revealed using an isotope-enabled global climate model, Nat. Commun., 10, 105-148, 2014b.

Celle-Jeanton, H., Huneau, F., Travi, Y., and Edmunds, W. M.: Twenty years of groundwater evolution in the Triassic sandstone aquifer of Lorraine: impacts on baseline water quality, Appl. Geochem., 24, 1198-1213, 2009.

Chen, X. Y., Bowler, J. M., and Magee, J. W.: Late Cenozoic stratigraphy and hydrologic history of Lake Amadeus, a central Australian playa, Aust. J. Earth Sci., 40, 1-14, 1993.

Chen, Z., Jixiang, Q., Jianming, X., Jiaming, X., Hao, Y., and Yunju, N.: Paleoclimatic interpretation of the past $30 \mathrm{ka}$ from isotopic studies of the deep confined aquifer of the North China plain, Appl. Geochem., 18, 997-1009, 2003.

Ciais, P. and Jouzel, J.: Deuterium and oxygen 18 in precipitation: Isotopic model, including mixed cloud processes, J. Geophys. Res., 99, 16793-16803, 1994.

Clark, J. F., Stute, M., Schlosser, P., Drenkard, S., and Bonani, G.: A tracer study of the Floridan aquifer in southeastern Georgia: Implications for groundwater flow and paleoclimate, Water Resour. Res., 33, 281-289, 1997.

Clark, P. U., Dyke, A. S., Shakun, J. D., Carlson, A. E., Clark, J., Wohlfarth, B., Mitrovica, J. X., Hostetler, W. S., and McCabe, A. M.: The last glacial maximum, Science, 325, 710-714, 2009.

Clark, P. U., Shakun, J. D., Baker, P. A., Bartlein, P. J., Brewer, S., Brook, E., Carlson, A. E., Cheng, H., Kaufman, D. S., Liu, Z., Marchitto, T. M., Mix, A. C., Morrill, C., Otto-Bliesner, B. L., Pahnke, K., Russell, J. M., Whitlock, C., Adkins, J. F., Blois, J. L., Clark, J., Colman, S. M., Curry, W. B., Flower, B. P., He, F., Johnson, T. C., Lynch-Stieglitz, J., Markgraf, V., McManus, J., Mitrovica, J. X., Moreno, P. I., Williams, J. W.: Global climate evolution during the last deglaciation, P. Natl. Acad. Sci. USA, 109, E1134-E1142, 2012.

Corcho Alvarado, J. A., Leuenberger, M., Kipfer, R., Paces, T., and Purtschert, R.: Reconstruction of past climate conditions over central Europe from groundwater data, Quaternary Sci. Rev., 30, 3423-3429, 2011.

Cosford, J., Qing, H., Yuan, D., Zhang, M., Holmden, C., Patterson, W., and Hai, C.: Millennial-scale variability in the Asian monsoon: Evidence from oxygen isotope records from stalagmites in southeastern China, Palaeogeogr. Palaeocl., 266, 3-12, 2008.

Cruz, F. W., Burns, S. J., Karmann, I., Sharp, W. D., Vuille, M., Cardoso, A. O., Ferrari, J. A., Dias, P. L. S., and Viana, O.: Insolation-driven changes in atmospheric circulation over the past 116000 years in subtropical Brazil, Nature, 434, 63-66, 2005.

Currell, M., Cendón, D. I., and Cheng, X.: Analysis of environmental isotopes in groundwater to understand the response of a vulnerable coastal aquifer to pumping: Western Port Basin, southeastern Australia, Hydrogeology J., 21, 1413-1427, 2013.

Currell, M. J., Han, D., Chen, Z., and Cartwright, I.: Sustainability of groundwater usage in northern China: dependence on palaeowaters and effects on water quality, quantity and ecosystem health, Hydrol. Process., 26, 4050-4066, 2012.

Cuthbert, M. O., Baker, A., Jex, C. N., Graham, P. W., Treble, P. C., Andersen, M. S., and Acworth, I. R.: Drip water isotopes in semi-arid karst: implications for speleothem paleoclimatology, Earth Planet. Sci. Lett., 395, 194-204, 2014a.
Cuthbert, M. O., Rau, G. C., Andersen, M. S., Roshan, H., Rutlidge, H., Marjo, C. E., Markowska, M., Jex, C. N., Graham, P. W., Mariethoz, G., Acwoth, R. I., and Baker, A.: Evaporative cooling of speleothem drip water, Scientific Reports, 4, 1-7, $2014 \mathrm{~b}$.

Daëron, M., Guo, W., Eiler, J., Genty, D., Blamart, D., Boch, R., Drysdale, R., Maire, R., Wainer, K., and Zanchetta, G.: ${ }^{13} \mathrm{C}^{18} \mathrm{O}$ clumping in speleothems: Observations from natural caves and precipitation experiments, Geochim. Cosmochim. Ac., 75, 33033317, 2011.

Dansgaard, W.: Stable isotopes in precipitation, Tellus, 16, 436468, 1964.

Dansgaard, W. and Tauber, H.: Glacier oxygen-18 content and Pleistocene ocean temperatures, Science, 166, 499-502, 1969.

Dansgaard, W., Clausen, H. B., Gundestrup, N., Hammer, C. U., Johnsen, S. F., Kristinsdottir, P. M., and Reeh, N.: A new Greenland deep ice core, Science, 218, 1273-1277, 1982.

Darling, W. G.: Hydrological factors in the interpretation of stable isotopic proxy data present and past: a European perspective, Quaternary Sci. Rev., 23, 743-770. 2004.

Darling, W. G.: The isotope hydrology of Quaternary climate change, J. Hum. Evol., 60, 417-427, 2011.

Darling, W. G., Edmunds, W. M., and Smedley, P. L.: Isotopic evidence for palaeowaters in the British Isles, Appl. Geochem., 12, 813-829, 1997.

Davison, M. R. and Airey, P. L.: The effect of dispersion on the establishment of a paleoclimatic record from groundwater, J. Hydrol., 58, 131-147, 1982.

Dayem, K. E., Molnar, P., Battisti, D. S., and Roe, G. H.: Lessons learned from oxygen isotopes in modern precipitation applied to interpretation of speleothem records of paleoclimate from eastern Asia, Earth Planet. Sci. Lett., 295, 219-230, 2010.

Deák, J., Stute, M., Rudolph, J., and Sonntag, C.: Determination of the flow regime of Quaternary and Pliocene layers in the Great Hungarian Plain (Hungary) by $\mathrm{D},{ }^{18} \mathrm{O},{ }^{14} \mathrm{C}$ and noble gas measurements, in: Isotope Techniques in Water Resources Development, International Atomic Energy Agency, Vienna, 335-350, 1987.

Denniston, R. F., González, L. A., Asmerom, Y., Sharma, R. H., and Reagan, M. K.: Speleothem evidence for changes in Indian summer monsoon precipitation over the last $\sim 2300$ years, Quaternary Res., 53, 196-202, 2000.

Dykoski, C. A., Edwards, R. L., Cheng, H., Yuan, D., Cai, Y., Zhang, M., Lin, Y., Qing, J., An, Z., and Revenaugh, J.: A highresolution, absolute-dated Holocene and deglacial Asian monsoon record from Dongge Cave, China, Earth Planet. Sci. Lett., 233, 71-86, 2005

Eawag, A. F., Eicher, U., Siegenthaler, U., and Birks, H. J. B.: Lateglacial climatic oscillations as recorded in Swiss lake sediments, J. Quaternary Sci., 7, 187-204, 1992.

Edmunds, W. M.: Palaeoclimate and groundwater evolution in Africa-implications for adaptation and management, Hydrolog. Sci. J., 54, 781-792, 2009.

Edmunds, W. M. and Milne, C. (Eds.): Palaeowaters in coastal Europe: Evolution of Groundwater since the late Pleistocene, Geol. Society Special. Publication, 189, Geological Society of London, London, 1-344, 2001.

Edwards, T. W. D. and McAndrews, J. H.: Paleohydrology of a Canadian Shield lake inferred from ${ }^{18} \mathrm{O}$ in sediment cellulose, Can. J. Earth Sci., 26, 1850-1859, 1989. 
Emiliani, C.: Pleistocene temperatures, J. Geol., 538-578, 1955.

Evaristo, J., Jasechko, S., and McDonnell, J. J.: Global separation of plant transpiration from groundwater and streamflow, Nature, 525, 91-94, 2015.

Fábián, S. Á., Kovács, J., Varga, G., Sipos, G., Horváth, Z., ThamóBozsó, E., and Tóth, G.: Distribution of relict permafrost features in the Pannonian Basin, Hungary, Boreas, 43, 722-732, 2014.

Fawcett, P. J., Ágústsdóttir, A. M., Alley, R. B., and Shuman, C. A.: The Younger Dryas termination and North Atlantic Deep Water formation: Insights from climate model simulations and Greenland ice cores, Paleoceanography, 12, 23-38, 1997.

Feng, W., Casteel, R. C., Banner, J. L., and Heinze-Fry, A.: Oxygen isotope variations in rainfall, drip-water and speleothem calcite from a well-ventilated cave in Texas, USA: Assessing a new speleothem temperature proxy, Geochim. Cosmochim. Ac., 127, 233-250, 2014.

Ferguson, G. A. and Jasechko, S.: The isotopic composition of the Laurentide ice sheet and fossil groundwater, Geophys. Res. Lett., 42, 4856-4861, 2015.

Ferguson, G. A., Betcher, R. N., and Grasby, S. E.: Hydrogeology of the Winnipeg formation in Manitoba, Canada, Hydrogeol. J., 15, 573-587, 2007.

Field, R. D., Kim, D., LeGrande, A. N., Worden, J., Kelley, M., and Schmidt, G. A.: Evaluating climate model performance in the tropics with retrievals of water isotopic composition from Aura TES, Geophys. Res. Lett., 41, 6030-6036, 2014.

Fleitmann, D., Cheng, H., Badertscher, S., Edwards, R. L., Mudelsee, M., Göktürk, O. M., Fankhauser, A., Pickering, R., Raible, C. C., Matter, A., Kramers, J., and Tüysüz, O: Timing and climatic impact of Greenland interstadials recorded in stalagmites from northern Turkey, Geophys. Res. Lett., 36, L19707, doi:10.1029/2009GL040050, 2009.

Frumkin, A., Ford, D. C., and Schwarcz, H. P.: Continental oxygen isotopic record of the last 170000 years in Jerusalem, Quaternary Res., 51, 317-327, 1999.

Galego Fernandes, P. and Carreira, P. M.: Isotopic evidence of aquifer recharge during the last ice age in Portugal, J. Hydrol., 361, 291-308, 2008.

Garreaud, R. D., Vuille, M., Compagnucci, R., and Marengo, J.: Present-day south american climate, Palaeogeogr. Palaeocl., 281, 180-195, 2009.

Gat, J. R., Mazor, E., and Tzur, Y.: The stable isotope composition of mineral waters in the Jordan Rift Valley, J. Hydrol., 7, 334$352,1969$.

Gibson, J. J., Birks, S. J., and Edwards, T. W. D.: Global prediction of $\delta_{A}$ and $\delta^{2} \mathrm{H}-\delta^{18} \mathrm{O}$ evaporation slopes for lakes and soil water accounting for seasonality, Global Biogeochem. Cy., 22, GB2031, 2008.

Grabczak, J., Różański, K., Maloszewski, P., and Zuber, A.: Estimation of the tritium input function with the aid of stable isotopes, Catena, 11, 105-114, 1984.

Grasby, S. E. and Chen, Z.: Subglacial recharge into the Western Canada Sedimentary Basin-Impact of Pleistocene glaciation on basin hydrodynamics, Geol. Soc. Am. Bull., 117, 500-514, 2005.

Guendouz, A., Moulla, A. S., Edmunds, W. M., Shand, P., Poole, J., Zouari, K., and Mamou, A.: Palaeoclimatic information contained in groundwaters of the Grnad Erg Oriental, northern Africa, in: Isotope Techniques in the study of Environmental Change, International Atomic Energy Agency, 555-571, 1998.
Hagedorn, B.: Hydrochemical and ${ }^{14} \mathrm{C}$ constraints on groundwater recharge and interbasin flow in an arid watershed: Tule Desert, Nevada, J. Hydrol., 523, 297-308, 2015.

Hamouda, M. F. B., Tarhouni, J., Leduc, C., and Zouari, K.: Understanding the origin of salinization of the Plio-quaternary eastern coastal aquifer of Cap Bon (Tunisia) using geochemical and isotope investigations, Environ. Earth. Sci., 63, 889-901, 2011.

Han, D., Kohfahl, C., Song, X., Xiao, G., and Yang, J.: Geochemical and isotopic evidence for palaeo-seawater intrusion into the south coast aquifer of Laizhou Bay, China, Appl. Geochem., 26, 863883, 2011.

Harmon, R. S., Thompson, P., Schwarcz, H. P., and Ford, D. C.: Late Pleistocene paleoclimates of North America as inferred from stable isotope studies of speleothems, Quaternary Res., 9, 54-70, 1978.

Harmon, R. S., Schwarcz, H. P., Ford, D. C., and Koch, D. L.: An isotopic paleotemperature record for late Wisconsinan time in northeast Iowa, Geology, 7, 430-433, 1979.

Harrington, G. A., Cook, P. G., and Herczeg, A. L.: Spatial and temporal variability of groundwater recharge in central Australia: a tracer approach, Groundwater, 40, 518-528, 2002.

Harrison, S. P. and Prentice, I. C.: Climate and $\mathrm{CO}_{2}$ controls on global vegetation distribution at the last glacial maximum: analysis based on palaeovegetation data, biome modelling and palaeoclimate simulations, Glob. Change Biol., 9, 983-1004, 2003.

Hoffmann, G., Ramirez, E., Taupin, J. D., Francou, B., Ribstein, P., Delmas, R., Dürr, H., Gallaire, R., Simões, J., Schotterer, U. Stievenard, M., and Werner, M.: Coherent isotope history of Andean ice cores over the last century, Geophys. Res. Lett., 30, 1179, doi:10.1029/2002GL014870, 2003.

James, E. W., Banner, J. L., and Hardt, B.: A global model for cave ventilation and seasonal bias in speleothem paleoclimate records, Geochem. Geophys. Geosyst., 16, 1044-1051, doi:10.1002/2014GC005658, 2015.

Jasechko, S., Birks, S. J., Gleeson, T., Wada, Y., Fawcett, P. J., Sharp, Z. D., McDonnell, J. J., and Welker, J. M.: The pronounced seasonality of global groundwater recharge, Water Res. Res., 50, 8845-8867, 2014.

Jiráková, H., Huneau, F., Celle-Jeanton, H., Hrkal, Z., and La Coustumer, P. L.: Insights into palaeorecharge conditions for European deep aquifers, Hydrogeology J., 19, 1545-1562, 2011.

Johnsen, S. J., Dahl-Jensen, D., Gundestrup, N., Steffensen, J. P., Clausen, H. B., Miller, H., Masson-Delmotte, V., Sveinbjörnsdottir, A. E., and White, J.: Oxygen isotope and palaeotemperature records from six Greenland ice-core stations: Camp Century, Dye-3, GRIP, GISP2, Renland and NorthGRIP, J. Quat. Sci., 16, 299-307, 2001.

Jones, I. C., Banner, J. L., and Humphrey, J. D.: Estimating recharge in a tropical karst aquifer, Water Resour. Res., 36, 1289-1299, 2000.

Jouzel, J., Hoffmann, G., Koster, R. D., and Masson V.: Water isotopes in precipitation: data/model comparison for present-day and past climates, Quat. Sci. Rev. 19, 363-379, 2000.

Justino, F., Timmermann, A., Merkel, U., and Souza, E. P.: Synoptic reorganization of atmospheric flow during the Last Glacial Maximum, J. Climate, 18, 2826-2846, 2005.

Kluge, T. and Affek, H. P.: Quantifying kinetic fractionation in Bunker Cave speleothems using $\Delta_{47}$, Quat. Sci. Rev., 49, 8294, 2012. 
Kluge, T., Affek, H. P., Marx, T., Aeschbach-Hertig, W., Riechelmann, D. F. C., Scholz, D., Riechelmann, S., Immenhauser, A., Richter, D. K., Fohlmeister, J., Wackerbarth, A., Mangini, A., and Spötl, C.: Reconstruction of drip-water $\delta^{18} \mathrm{O}$ based on calcite oxygen and clumped isotopes of speleothems from Bunker Cave (Germany), Clim. Past, 9, 377-391, doi:10.5194/cp-9-3772013, 2013.

Lachniet, M. S., Asmerom, Y., Burns, S. J., Patterson, W. P., Polyak, V. J., and Seltzer, G. O.: Tropical response to the $8200 \mathrm{yr}$ BP cold event? Speleothem isotopes indicate a weakened early Holocene monsoon in Costa Rica, Geology, 32, 957-960, 2004.

Lee, J.-E., Pierrehumbert, R., Swann, A., and Lintner, B. R.: Sensitivity of stable water isotopic values to convective parameterization schemes, Geophys. Res. Lett., 36, L23801, doi:10.1029/2009GL040880, 2009.

Lee, J.-E., Risi, C., Fung, I., Worden, J., Scheepmaker, R. A., Lintner, B., and Frankenberg, C.: Asian monsoon hydrometeorology from TES and SCIAMACHY water vapor isotope measurements and LMDZ simulations: Implications for speleothem climate record interpretation, J. Geophys. Res., 117, D15112, doi:10.1029/2011JD017133, 2012.

LeGrande, A. N. and Schmidt, G. A.: Global gridded data set of the oxygen isotopic composition in seawater, Geophys. Res. Lett., 33, L12604, doi:10.1029/2006GL026011, 2006.

LeGrande, A. N. and Schmidt, G. A.: Ensemble, water isotope-enabled, coupled general circulation modeling insights into the $8.2 \mathrm{ka}$ event, Paleoceanography, 23, PA3207, doi:10.1029/2008PA001610, 2008.

LeGrande, A. N. and Schmidt, G. A.: Sources of Holocene variability of oxygen isotopes in paleoclimate archives, Clim. Past, 5, 441-455, doi:10.5194/cp-5-441-2009, 2009.

Licciardi, J. M., Teller, J. T., and Clark, P. U.: Freshwater routing by the Laurentide Ice Sheet during the last deglaciation, in: Mechanisms of global climate change at millennial time scales, edited by: Clark, P. U., Webb, R. S., and Keigwin, L. D., AGU Geophysical Monograph, 112, 177-201, 1999.

Le Gal La Salle, C., Marlin, C., Savoye, S., and Fontes, J. C.: Geochemistry and ${ }^{14} \mathrm{C}$ dating of groundwaters from Jurassic aquifers of North Aquitaine Basin (France), Appl. Geochem., 11, 433445, 1996.

Lekshmy, P. R., Midhun, M., Ramesh, R., and Jani, R. A: ${ }^{18}$ O depletion in monsoon rain relates to large scale organized convection rather than the amount of rainfall, Scientific Reports, 4, 5661, doi:10.1038/srep05661, 2014.

Leng, M. J. and Marshall, J. D.: Palaeoclimate interpretation of stable isotope data from lake sediment archives, Quaternary Sci. Rev., 23, 811-831, 2004.

Levin, N. E., Zipser, E. J., and Cerling, T. E.: Isotopic composition of waters from Ethiopia and Kenya: Insights into moisture sources for eastern Africa, J. Geophys. Res., 114, D23306, doi:10.1029/2009JD012166, 2009.

Lewis, S. C., LeGrande, A. N., Kelley, M., and Schmidt, G. A.: Water vapour source impacts on oxygen isotope variability in tropical precipitation during Heinrich events, Clim. Past, 6, 325-343, doi:10.5194/cp-6-325-2010, 2010.

Lewis, S. C., Gagan, M. K., Ayliffe, L. K., Zhao, J.-X., Hantoro, W. S., Treble, P. C., Hellstrom, J. C., LeGrande, A. N., Kelley, M., Schmidt, G. A., and Suwargadi, B. W.: High-resolution stalagmite reconstructions of Australian-Indonesian monsoon rainfall variability during Heinrich stadial 3 and Greenland interstadial 4, Earth Planet. Sci. Lett., 303, 133-142, 2011.

Li, J., Pang, Z., Froehlich, K., Huang, T., Kong, Y., Song, W., and Yun, H.: Paleo-environment from isotopes and hydrochemistry of groundwater in East Junggar Basin, Northwest China, J. Hydrol., 529, 650-661, doi:10.1016/j.jhydrol.2015.02.019, 2015.

Liu, X., Shen, J., Wang, S., Wang, Y., and Liu, W.: Southwest monsoon changes indicated by oxygen isotope of ostracode shells from sediments in Qinghai Lake since the late Glacial, Chinese Science Bulletin, 52, 539-544, 2007.

Liu, Z., Yoshimura, K., Bowen, G. J., and Welker, J. M.: PacificNorth American Teleconnection Controls on Precipitation Isotopes $\left(\delta^{18} \mathrm{O}\right)$ across the Contiguous United States and Adjacent Regions: A GCM-Based Analysis, J. Climate, 27, 1046-1061, 2014a.

Liu, Z., Yoshimura, K., Bowen, G. J., Buenning, N. H., Risi, C., Welker, J. M., and Yuan, F.: Paired oxygen isotope records reveal modern North American atmospheric dynamics during the Holocene, Nat. Commun., 5, 1-7, 2014b.

Loosli, H. H., Aeschbach-Hertig, W., Barbecot, F., Blaser, P., Darling, W. G., Dever, L., Edmunds, W. M., Kipfer, R., Purtschert, R., and Walraevens, K.: Isotopic methods and their hydrogeochemical context in the investigation of palaeowaters, Geological Society, London, Special Publications, 189, 193-212, 2001.

Ma, J. Z., Ding, Z., Gates, J. B., and Su, Y.: Chloride and the environmental isotopes as the indicators of the groundwater recharge in the Gobi Desert, northwest China, Environ. Geol., 55, $1407-$ 1419, 2008.

Madioune, D. H., Faye, S., Orban, P., Brouyère, S., Dassargues, A., Mudry, J., Stumpp, C., and Maloszewski, P.: Application of isotopic tracers as a tool for understanding hydrodynamic behavior of the highly exploited Diass aquifer system (Senegal), J. Hydrol., 511, 443-459, 2014.

Maher, B. A. and Thompson, R.: Oxygen isotopes from Chinese caves: records not of monsoon rainfall but of circulation regime, J. Quaternary Sci., 27, 615-624, 2012.

MARGO Members: Constraints on the magnitude and patterns of ocean cooling at the Last Glacial Maximum, Nat. Geosci., 2, 127-132, 2009.

Masson-Delmotte, V., Landais, A. Stievenard, M., Cattani, O., Falourd, S., Jouzel J., Johnsen, S. J., Dahl-Jensen, D., Sveinsbjornsdottir, A., White, J. W. C., Popp, T., and Fischer, H.: Holocene climatic changes in Greenland: Different deuterium excess signals at Greenland Ice Core Project (GRIP) and NorthGRIP, J. Geophys. Res., 110, D14102, doi:10.1029/2004JD005575, 2005.

McDermott, F., Mattey, D. P., and Hawkesworth, C.: Centennialscale Holocene climate variability revealed by a high-resolution speleothem $\delta^{18} \mathrm{O}$ record from SW Ireland, Science, 294, 13281331, 2001.

McIntosh, J. C., Schlegel, M. E., and Person, M.: Glacial impacts on hydrologic processes in sedimentary basins: evidence from natural tracer studies, Geofluids, 12, 7-21, 2012.

Melikadze, G., Jukova, N., Todadze, M., Vepkhvadze, S., Kapanadze, N., Chankvetadze, A., Jimsheladze, T, and Vitvar, T.: Evaluation of recharge origin of groundwater in the Alazani-Iori basins, using hydrochemical and isotope approaches, Journal of Georgian Geophysical Society, 17a, 53-64, 2014. 
Menking, K. M., Bischoff, J. L., Fitzpatrick, J. A., Burdette, J. W., and Rye, R. O.: Climatic/hydrologic oscillations since $155000 \mathrm{yr}$ BP at Owens Lake, California, reflected in abundance and stable isotope composition of sediment carbonate, Quaternary Res., 48, 58-68, 1997.

Miller, G. H., Magee, J. W., and Jull, A. J. T.: Low-latitude glacial cooling in the Southern Hemisphere from amino-acid racemization in emu eggshells, Nature, 385, 241-244, 1997.

Morley, D. W., Leng, M. J., Mackay, A. W., and Sloane, H. J.: Late glacial and Holocene environmental change in the Lake Baikal region documented by oxygen isotopes from diatom silica, Global Planet. Change, 46, 221-233, 2005.

Morrissey, S. K., Clark, J. F., Bennett, M., Richardson, E., and Stute, M.: Groundwater reorganization in the Floridan aquifer following Holocene sea-level rise, Nat. Geosci., 3, 683-687, 2010.

Münnich, K. O.: Messungen des $\mathrm{C}^{14}$-Gehaltes von hartem Grundwasser, Naturwissenschaften, 44, 32-33, 1957.

Münnich, K. O., Roether, W., and Thilo, L.: Dating of groundwater with tritium and ${ }^{14} \mathrm{C}$, Isotopes in Hydrology, Proceedings of the Symposium on isotopes in hydrology, International Atomic Energy Agency, Vienna, 305-320, 1967.

Mulitza, S., Prange, M., Stuut, J.-B., Zabel, M., von Dobeneck, T., Itambi, A. C., Nizou, J., Schulz, M., and Wefer, G.: Sahel megadroughts triggered by glacial slowdowns of Atlantic meridional overturning, Paleoceanography, 23, PA4206, doi:10.1029/2008PA001637, 2008.

Nanson, G., Price, D., and Short, S.: Wetting and drying of Australia over the past $300 \mathrm{ka}$, Geology, 20, 791-794, 1992.

Négrel, P. and Petelet-Giraud, E.: Isotopes in groundwater as indicators of climate changes, Trends Anal. Chem., 30, 1279-1290, 2011.

Nikolayev, V. I. and Mikhalev, D. V.: An oxygen-isotope paleothermometer from ice in Siberian permafrost, Quaternary Res., 43, 14-21, 1995.

Noone, D. and Sturm, C.: Comprehensive dynamical models of global and regional water isotope distributions. In: Isoscapes: Understanding Movement, Pattern, and Process on Earth through Isotope Mapping, Springer, 195-219, 2010.

Oster, J. L., Ibarra, D. E., Winnick, M. J., and Maher, K.: Steering of westerly storms over western North America at the Last Glacial Maximum, Nat. Geosci., 8, 201-205, 2015.

Otto-Bliesner, B. L., Russell, J. M., Clark, P. U., Liu, Z., Overpeck, J. T., Konecky, B., deMenocal, P., Nicholson, S. E., He, F., and $\mathrm{Lu}, \mathrm{Z}$.: Coherent changes of southeastern equatorial and northern African rainfall during the last deglaciation, Science, 346, 12231227, 2014.

Partin, J. W., Cobb, K. M., Adkins, J. F., Clark, B., and Fernandez, D. P.: Millennial-scale trends in west Pacific warm pool hydrology since the Last Glacial Maximum, Nature, 449, 452-455, 2007.

Partin, J. W., Jenson, J. W., Banner, J. L., Quinn, T. M., Taylor, F. W., Sinclair, D., Hardt, B., Lander, M. A., Bell, T., Miklavic, B., Jocson, J. M. U., and Taboroši, D.: Relationship between modern rainfall variability, cave dripwater, and stalagmite geochemistry in Guam, USA, Geochem. Geophys. Geosys., 13, Q03013, doi:10.1029/2011GC003930, 2012.

Pausata, F. S. R., Li, C., Wettstein, J. J., Nisancioglu, K. H., and Battisti, D. S.: Changes in atmospheric variability in a glacial climate and the impacts on proxy data: a model intercomparison, Clim. Past, 5, 489-502, doi:10.5194/cp-5-489-2009, 2009.

Pausata, F. S. R., Battisti, D. S., Nisancioglu, K. H., and Bitz, C. M.: Chinese stalagmite $\delta^{18} \mathrm{O}$ controlled by changes in the Indian monsoon during a simulated Heinrich event, Nat. Geosci., 4, 474-480, 2011a.

Pausata, F. S. R., Li, C., Wettstein, J. J., Kageyama, M., and Nisancioglu, K. H.: The key role of topography in altering North Atlantic atmospheric circulation during the last glacial period, Clim. Past, 7, 1089-1101, doi:10.5194/cp-7-1089-2011, 2011 b.

Pearson, F. J. and White, D. E.: Carbon 14 ages and flow rates of water in Carrizo Sand, Atascosa County, Texas, Water Resour. Res., 3, 251-261, 1967.

Pedro, J. B., van Ommen, T. D., Rasmussen, S. O., Morgan, V. I., Chappellaz, J., Moy, A. D., Masson-Delmotte, V., and Delmotte, M.: The last deglaciation: timing the bipolar seesaw, Clim. Past, 7, 671-683, doi:10.5194/cp-7-671-2011, 2011.

Peltier, W. R.: Ice age paleotopography, Science, 265, 195-201, 1994.

Phillips, F. M., Peeters, L. A., Tansey, M. K., and Davis, S. N.: Paleoclimatic inferences from an isotopic investigation of groundwater in the central San Juan Basin, New Mexico, Quaternary Res., 26, 179-193, 1986.

Plummer, L. N.: Stable isotope enrichment in paleowaters of the southeast Atlantic Coastal Plain, United States, Science, 262, 2016-2020, 1993.

Plummer, L. N., Eggleston, J. R., Andreasen, D. C., Raffensperger, J. P., Hunt, A. G., and Casile, G. C.: Old groundwater in parts of the upper Patapsco aquifer, Atlantic Coastal Plain, Maryland, USA: evidence from radiocarbon, chlorine- 36 and helium-4, Hydrogeology J., 20, 1269-1294, 2012.

Powers, L. A., Johnson, T. C., Werne, J. P., Castañeda, I. S., Hopmans, E. C., Sinninghe Damsté, J. S., and Schouten, S.: Large temperature variability in the southern African tropics since the Last Glacial Maximum, Geophys. Res. Lett., 32, L08706, doi:10.1029/2004GL022014, 2005.

Purdy, C. B., Helz, G. R., Mignerey, A. C., Kubik, P. W., Elmore, D., Sharma, P., and Hemmick, T.: Aquia Aquifer Dissolved $\mathrm{Cl}^{-}$ and ${ }^{36} \mathrm{Cl} / \mathrm{Cl}$ : implications for flow velocities, Water Resour. Res., 32, 1163-1171, 1996.

Risi, C., Bony, S., Vimeux, F., Descroix, L., Ibrahim, B. Lebreton, E. Mamadou, I., and Sultan, B.: What controls the isotopic composition of the African monsoon precipitation? Insights from event-based precipitation collected during the 2006 AMMA field campaign, Geophys. Res. Lett., 35, L24808, doi:10.1029/2008GL035920, 2008.

Risi, C., Bony, S., Vimeux, F., and Jouzel, J.: Water-stable isotopes in the LMDZ4 general circulation model: Model evaluation for present-day and past climates and applications to climatic interpretations of tropical isotopic records, J. Geophys. Res., 115, D12118, doi:10.1029/2009JD013255, 2010a.

Risi, C., Bony, S., Vimeux, F., Frankenberg, C., Noone, D., and Worden, J.: Understanding the Sahelian water budget through the isotopic composition of water vapor and precipitation, J. Geophys. Res., 115, D24110, doi:10.1029/2010JD014690, $2010 \mathrm{~b}$.

Risi, C., Noone, D., Frankenberg, C., and Worden, J.: Role of continental recycling in intraseasonal variations of continental moisture as deduced from model simulations and water vapor isotopic measurements, Water Resour. Res., 49, 4136-4156, 2013. 
Rozanski, K.: Deuterium and oxygen-18 in European groundwaters-links to atmospheric circulation in the past, Chem. Geol., 52, 349-363, 1985.

Rozanski, K., Araguás-Araguás, L., and Gonfiantini, R.: Isotopic patterns in modern global precipitation, in: Climate Change in Continental Isotopic Records, edited by: Swart, P. K., Lohmann, K. C., McKenzie, J., and Savin, S., Geoph. Monogr. Series, 78, 1-36, 1993.

Sachse, D., Radke, J., and Gleixner, G.: Hydrogen isotope ratios of recent lacustrine sedimentary n-alkanes record modern climate variability, Geochim. Cosmochim. Ac., 68, 4877-4889, 2004.

Salati, E., Menezes Leal, J., and Mendes Campos, M.: Environmental isotopes used in a hydrogeological study of northeastern Brazil, in: Isotope Techniques in Groundwater Hydrology 1974, 1, 379-398, 1974.

Samborska, K., Różkowski, A., and Małoszewski, P.: Estimation of groundwater residence time using environmental radioisotopes $\left({ }^{14} \mathrm{C}, \mathrm{T}\right)$ in carbonate aquifers, southern Poland, Isot. Environ. Health Stud., 49, 73-97, 2013.

Samuels-Crow, K. E., Galewsky, J., Hardy, D. R., Sharp, Z. D., Worden, J., and Braun, C.: Upwind convective influences on the isotopic composition of atmospheric water vapor over the tropical Andes, J. Geophys. Res., 119, 7051-7063, 2014.

Scanlon, B. R., Keese, K., Reedy, R. C., Simunek, J., and Andraski, B. J.: Variations in flow and transport in thick desert vadose zones in response to paleoclimatic forcing (0-90 kyr): Field measurements, modeling, and uncertainties, Water Resour. Res., 39, 1179, doi:10.1029/2002WR001604, 2003.

Schefuß, E., Kuhlmann, H., Mollenhauer, G., Prange, M., and Pätzold, J.: Forcing of wet phases in southeast Africa over the past 17000 years, Nature, 480, 509-512, 2011.

Schiavo, M. A., Hauser, S., and Povinec, P. P.: Stable isotopes of water as a tool to study groundwater-seawater interactions in coastal south-eastern Sicily, J. Hydrol., 364, 40-49, 2009.

Schlegel, M. E., Mayo, A. L., Nelson, S., Tingey, D., Henderson, R., and Eggett, D.: Paleo-climate of the Boise area, Idaho from the last glacial maximum to the present based on groundwater $\delta^{2} \mathrm{H}$ and $\delta^{18} \mathrm{O}$ compositions, Quaternary Res., 71, 172-180. 2009.

Scholl, M. A., Shanley, J. B., Zegarra, J. P., and Coplen, T. B.: The stable isotope amount effect: New insights from NEXRAD echo tops, Luquillo Mountains, Puerto Rico, Water Resour. Res., 45, W12407 doi:10.1029/2008WR007515, 2009.

Schrag, D. P., Hampt, G., and Murray, D. W.: Pore fluid constraints on the temperature and oxygen isotopic composition of the glacial ocean, Science, 272, 1930-1932, 1996.

Schrag, D. P., Adkins, J. F., McIntyre, K., Alexander, J. L., Hodell, D. A., Charles, C. D., and McManus, J. F.: The oxygen isotopic composition of seawater during the Last Glacial Maximum, Quaternary Sci. Rev., 21, 331-342, 2002.

Shah, A. M., Morrill, C., Gille, E. P., Gross, W. S., Anderson, D. M., Bauer, B. A. Buckner, R., and Hartman, M.: Global speleothem oxygen isotope measurements since the Last Glacial Maximum, Dataset Papers in Geosciences, 9 pp., 2013.

Shakun, J. D. and Carlson, A. E.: A global perspective on Last Glacial Maximum to Holocene climate change, Quaternary Sci. Rev., 29, 1801-1816, 2010.

Simpson, E. S., Thorud, D. B., and Friedman, I.: Distinguishing seasonal recharge to groundwater by deuterium analysis in southern
Arizona, Proceedings of the Reeding Symposium, International Association of Scientific Hydrology, 113-121, 1972.

Sjostrom, D. J. and Welker, J. M.: The influence of air mass source on the seasonal isotopic composition of precipitation, eastern USA, J. Geochem. Explor., 102, 103-112, 2009.

Steen-Larsen, H. C., Masson-Delmotte, V., Hirabayashi, M., Winkler, R., Satow, K., Prié, F., Bayou, N., Brun, E., Cuffey, K. M., Dahl-Jensen, D., Dumont, M., Guillevic, M., Kipfstuhl, S., Landais, A., Popp, T., Risi, C., Steffen, K., Stenni, B., and Sveinbjörnsdottír, A. E.: What controls the isotopic composition of Greenland surface snow?, Clim. Past, 10, 377-392, doi:10.5194/cp-10-377-2014, 2014.

Stenni, B., Burion, D., Frezzotti, M., Albani, S., Barbante, C., Bard, E., Barnola, J.M., Baroni, M., Baumgartner, M., Bonazza, M., Capron, E., Castellano, E., Chappellaz, J., Delmonte, B., Falourd, S., Genoni, L., Iacumin, P., Jouzel, J., Kipfstuhl, S., Landais, A., Lemieux-Dudon, B., Maggi, V., Masson-Delmonte, V., Mazzola, C., Minster, B., Montagnat, M., Mulvaney, R., Narcisci, B., Oerter, H., Parrenin, F., Petit, J. R., Ritz, C., Scarchilli, C., Schilt, A., Schüpach, S., Schwander, J., Selmo, E., Sereri, M., Stocker, T. F., and Udisti, R.: Expression of the bipolar see-saw in Antarctic climate records during the last deglaciation, Nat. Geosci., 4, 46-49, 2011.

Stewart, M. K., Thomas, J. T., Norris, M., and Trompetter, V.: Paleogroundwater in the Moutere gravel aquifers near Nelson, New Zealand, Radiocarbon, 46, 517-529, 2004.

Stute, M. and Deak, J.: Environmental isotope study ${ }^{14} \mathrm{C},{ }^{13} \mathrm{C},{ }^{18} \mathrm{O}$, $\mathrm{D}$, noble gases on deep groundwater circulation systems in Hungary with reference to paleoclimate, Radiocarbon, 31, 902-918, 1989.

Stute, M., Schlosser, P., Clark, J. F., and Broecker, W. S.: Paleotemperatures in the southwestern United States derived from noble gases in ground water, Science, 256, 1000-1003, 1992.

Stute, M., Clark, J. F., Schlosser, P., Broecker, W. S., and Bonani, G.: A 30,000 yr continental paleotemperature record derived from noble gases dissolved in groundwater from the San Juan Basin, New Mexico, Quaternary Res., 43, 209-220, 1995a.

Stute, M., Forster, M., Frischkorn, H., Serejo, A., Clark, J. F., Schlosser, P., Broecker, W. S., and Bonani, G.: Cooling of tropical Brazil $\left(5^{\circ} \mathrm{C}\right)$ during the Last Glacial Maximum, Science, 269, 379-379, 1995b.

Sultan, M., Sturchio, N., Hassan, F. A., Hamdan, M. A. R., Mahmood, A. M., Alfy, Z. E., and Stein, T.: Precipitation source inferred from stable isotopic composition of Pleistocene groundwater and carbonate deposits in the Western desert of Egypt, Quaternary Res., 48, 29-37, 1997.

Tamers, M. A.: Radiocarbon ages of groundwater in an arid zone unconfined aquifer, in: Isotope techniques in the hydrologic cycle, edited by: Stout, G. E., American Geophysical Union Monograph, 11, 143-152, 1967.

Tan, M.: Circulation effect: response of precipitation $\delta^{18} \mathrm{O}$ to the ENSO cycle in monsoon regions of China, Climate Dyn., 42, 1067-1077, 2014.

Tharammal, T., Paul, A., Merkel, U., and Noone, D.: Influence of Last Glacial Maximum boundary conditions on the global water isotope distribution in an atmospheric general circulation model, Clim. Past, 9, 789-809, doi:10.5194/cp-9-789-2013, 2013.

Thatcher, L., Rubin, M., and Brown, G. F.: Dating desert groundwater, Science, 134, 105-106, 1961. 
Thompson, L. G., Mosley-Thompson, E., Davis, M. E., Bolzan, J. F., Dai, J., Yao, T., Gundestrup, N., Wu, X., Klein, L., Xie, Z.: Holocene-late Pleistocene climatic ice core records from Qinghai-Tibetan Plateau, Science, 246, 474-477, 1989.

Thompson, L. G., Mosley-Thompson, E., Davis, M. E., Lin, P. N., Henderson, K. A., Cole-Dai, J., Bolzan, J. F., and Liu, K. B.: Late glacial stage and Holocene tropical ice core records from Huascaran, Peru, Science, 269, 46-50, 1995.

Thompson, L. G., Yao, T., Davis, M. E., Henderson, K. A., MosleyThompson, E., Lin, P. N., Beer, J., Synal, H.-A., Cole-Dai, J., and Bolzan, J. F.: Tropical climate instability: The last glacial cycle from a Qinghai-Tibetan ice core, Science, 276, 1821-1825, 1997.

Thompson, L. G., Davis, M. E., Mosley-Thompson, E., Sowers, T. A., Henderson, K. A., Zagorodnov, V. S., Lin, P.-N., Mikhalenko, V. N., Campen, R. K., Bolzan, F. F., Cole-Dai, J., and Francou, B.: A 25 000-year tropical climate history from Bolivian ice cores, Science, 282, 1858-1864, 1998.

Thompson, L. G., Mosley-Thompson, E., Brecher, H., Davis, M., León, B., Les, D., Lin, P.-N., and Mountain, K.: Abrupt tropical climate change: Past and present, P. Natl. Acad. Sci. USA, 103, 10536-10543, 2006.

Tierney, J. E., Russell, J. M., Huang, Y., Damsté, J. S. S., Hopmans, E. C., and Cohen, A. S.: Northern hemisphere controls on tropical southeast African climate during the past 60000 years, Science, 322, 252-255, 2008.

Tierney, J. E., Smerdon, J. E., Anchukaitis, K. J., and Seager, R.: Multidecadal variability in East African hydroclimate controlled by the Indian Ocean, Nature, 493, 389-392, 2013.

Toscano, M. A., Peltier, W. R., and Drummond, R.: ICE-5G and ICE-6G models of postglacial relative sea-level history applied to the Holocene coral reef record of northeastern St Croix, USVI: investigating the influence of rotational feedback on GIA processes at tropical latitudes, Quaternary Sci. Rev., 30, 3032-3042, 2011

Ullman, D. J., LeGrande, A. N., Carlson, A. E., Anslow, F. S., and Licciardi, J. M.: Assessing the impact of Laurentide Ice Sheet topography on glacial climate, Clim. Past, 10, 487-507, doi:10.5194/cp-10-487-2014, 2014.

Varsányi, I., Palcsu, L., and Kovács, L. Ó.: Groundwater flow system as an archive of palaeotemperature: Noble gas, radiocarbon, stable isotope and geochemical study in the Pannonian Basin, Hungary, Appl. Geochem., 26, 91-104, 2011.

Vimeux, F., Gallaire, R., Bony, S., Hoffmann, G., and Chiang, J. C.: What are the climate controls on $\delta \mathrm{D}$ in precipitation in the Zongo Valley (Bolivia)? Implications for the Illimani ice core interpretation, Earth Planet. Sci. Lett., 240, 205-220, 2005.

Vimeux, F., Tremoy, G., Risi, C., and Gallaire, R.: A strong control of the South American SeeSaw on the intra-seasonal variability of the isotopic composition of precipitation in the Bolivian Andes, Earth Planet. Sci. Lett., 307, 47-58, 2011.

Vogel, J. C., Ehhalt, D., and Roether, W.: A survey of the natural isotopes of water in South Africa, Proceedings of Tokyo Conference on Radioisotopes in Hydrology, 407-416, 1963.

Vuille, M. and Werner, M.: Stable isotopes in precipitation recording South American summer monsoon and ENSO variability: observations and model results, Clim. Dyn., 25, 401-413, 2005.

Wada, Y., van Beek, L. P. H., van Kempen, C. M., Reckman, J. W. T. M., Vasek, S., and Bierkens, M. F. P.: Global deple- tion of groundwater resources, Geophys. Res. Lett., 38, L20402, doi:10.1029/2010GL044571, 2010.

Wagner, J. D. M., Cole, J. E., Beck, J. W., Patchett, P. J., Henderson, G. M., and Barnett, H. R.: Moisture variability in the southwestern United States linked to abrupt glacial climate change, Nat. Geosci. 3, 110-113, 2010.

Walker, M. J. C., Berkelhammer, M., Björck, S., Cwynar, L. C., Fisher, D. A., Long, A. J., Lowe, J. J., Newnham, R. M., Rasmussen, S. O., and Weiss, H.: Formal subdivision of the Holocene Series/Epoch: a Discussion Paper by a Working Group of INTIMATE (Integration of ice-core, marine and terrestrial records) and the Subcommission on Quaternary Stratigraphy (International Commission on Stratigraphy), J. Quaternary Sci., 27, 649-659, 2012.

Wang, Y. and Jiao, J. J.: Origin of groundwater salinity and hydrogeochemical processes in the confined Quaternary aquifer of the Pearl River Delta, China, J. Hydrol., 438, 112-124, 2012.

Wang, Y. J., Cheng, H., Edwards, R. L., An, Z. S., Wu, J. Y., Shen, C-C., and Dorale, J. A.: A high-resolution absolute-dated late Pleistocene monsoon record from Hulu Cave, China, Science, 294, 2345-2348, 2001.

Werner, M., Mikolajewicz, U., Heimann, M., and Hoffmann, G.: Borehole versus isotope temperatures on Greenland: Seasonality does matter, Geophys. Res. Lett., 27, 723-726, 2000.

Werner, M., Langebroek, P. M., Carlsen, T., Herold, M., and Lohmann, G.: Stable water isotopes in the ECHAM5 general circulation model: Toward high-resolution isotope modeling on a global scale, J. Geophys. Res., 116, D15109, doi:10.1029/2011JD015681, 2011.

Weyhenmeyer, C. E., Burns, S. J., Waber, H. N., Aeschbach-Hertig, W., Kipfer, R., Loosli, H. H., and Matter, A.: Cool glacial temperatures and changes in moisture source recorded in Oman groundwaters, Science, 287, 842-845, 2000.

Williams J. W.: Variations in tree cover in North America since the last glacial maximum, Global Planet. Change, 35, 1-23, 2003.

Williams, P. W., Neil, H. L., and Zhao, J. X.: Age frequency distribution and revised stable isotope curves for New Zealand speleothems: palaeoclimatic implications, Int. J. Speleol., 39, 99-112, 2010.

Winnick, M. J., Welker, J. M., and Chamberlain, C. P.: Stable isotopic evidence of El Niño-like atmospheric circulation in the Pliocene western United States, Clim. Past, 9, 903-912, doi:10.5194/cp-9-903-2013, 2013.

Winnick, M. J., Chamberlain, C. P., Caves, J. K., and Welker, J. M.: Quantifying the isotopic "continental effect", Earth Planet. Sci. Lett., 406, 123-133, 2014.

Wolfe, B. B., Edwards, T. W., Aravena, R., Forman, S. L., Warner, B. G., Velichko, A. A., and MacDonald, G. M.: Holocene paleohydrology and paleoclimate at treeline, north-central Russia, inferred from oxygen isotope records in lake sediment cellulose, Quaternary Res., 53, 319-329, 2000.

Wood, W. W., Rizk, Z. S., and Alsharhan, A. S.: Timing of recharge, and the origin, evolution and distribution of solutes in a hyperarid aquifer system, Developments in Water Science, 50, 295-312, 2003.

Yang, Y., Yuan, D., Cheng, H., Zhang, M., Qin, J., Lin, Y., XiaoYan, Z., and Edwards, R. L.: Precise dating of abrupt shifts in the Asian Monsoon during the last deglaciation based on stalagmite 
data from Yamen Cave, Guizhou Province, China, Science China Earth Sciences, 53, 633-641, 2010.

Yechieli, Y., Kafri, U., and Sivan, O.: The inter-relationship between coastal sub-aquifers and the Mediterranean Sea, deduced from radioactive isotopes analysis, Hydrogeology J., 17, 265274, 2009.

Yoshimura, K., Oki, T., Ohte, N., and Kanae, S.: A quantitative analysis of short-term ${ }^{18} \mathrm{O}$ variability with a Rayleightype isotope circulation model, J. Geophys. Res., 108, 4647, doi:10.1029/2003JD003477, 2003.

Yoshimura, K., Kanamitsu, M., Noone, D., and T. Oki, T.: Historical isotope simulation using Reanalysis atmospheric data, J. Geophys. Res., 113, D19108, doi:10.1029/2008JD010074, 2008.
Yuan, D., Cheng, H., Edwards, R., Dykoski, C. A., Kelly, M. J., Zhang, M., Qing, J., Lin, Y., Wang, Y., Wu, J., Dorale, J. A., An, Z., and Cai, Y.: Timing, Duration, and Transitions of the Last Interglacial Asian Monsoon, Science, 23, 575-578, 2004.

Zuber, A., Weise, S. M., Motyka, J., Osenbrück, K., and Różański, K.: Age and flow pattern of groundwater in a Jurassic limestone aquifer and related Tertiary sands derived from combined isotope, noble gas and chemical data, J. Hydrol., 286, 87-112, 2004. 